HORVITZ, María Inés. "La insostenible situación de la ejecución de las penas privativas de libertad: ¿vigencia del Estado de derecho o estado de naturaleza?”.

Polít. crim. Vol. 13, No 26 (Diciembre 2018) Art. 7, pp. 904-951.

[http://www.politicacriminal.cl/Vol_13/n_26/Vol13N26A7.pdf]

\title{
La insostenible situación de la ejecución de las penas privativas de libertad: ¿vigencia del Estado de derecho o estado de naturaleza?
}

\section{The untenable situation of the execution of custodial sentences: validity of the rule of law or state of nature?}

\author{
María Inés Horvitz Lennon* \\ Doctora por la Universidad Autónoma de Barcelona (España) \\ Profesora asociada del Departamento de Ciencias Penales, Universidad de Chile \\ mhorvitz@derecho.uchile.cl
}

\begin{abstract}
Resumen
El presente artículo aborda la evolución general de la privación de libertad, primero como custodia de aseguramiento y, después, como pena propiamente tal para indagar en los dispositivos ideológicos que han asegurado históricamente y hasta el día de hoy la exclusión de los condenados a penas de cárcel de su consideración como sujetos titulares de derechos, cuyo ejercicio no debiera ser afectado sino únicamente respecto del o los derechos comprometidos con la naturaleza de la(s) pena(s) impuesta(s). En particular, se examinan los discursos teóricos que han permitido la "administrativización" de la ejecución de las penas privativas de libertad a partir de su disociación con la fase de su imposición en la sentencia, y que han conducido a la atribución de distintos fines a la pena según cuál sea el momento en que se expresa la práctica punitiva estatal. La consecuencia ha sido la comprensión (de) que el derecho penal, con sus principios y garantías, solo llega hasta el momento de la imposición judicial de la pena; la cárcel queda fuera y también el estado de derecho.
\end{abstract}

\begin{abstract}
This article deals with the general evolution of deprivation of liberty, first as custody and then as a proper penalty, to investigate the ideological devices that have historically ensured the exclusion of those sentenced to imprisonment of their consideration as rights holders, whose exercise should not be affected but only with respect to the rights or duties committed with the nature of the sentence (s) imposed. In particular, it examines the theoretical discourses that have allowed the "administrativization" of the execution of imprisonment sentences since its dissociation with the phase of its imposition in the sentence have led to the attribution of different ends to the penalty of imprisonment, depending on when the punitive state practice is expressed. The consequence has been the understanding (of) that criminal law, with its principles and guarantees, only reaches the moment of judicial imposition of sentence; jail is out, and so is the rule of law.
\end{abstract}


Un malvado, pero que no ha roto los pactos de una sociedad de que no era miembro, puede ser temido, y por tanto desterrado y excluido, en virtud de la fuerza superior de la sociedad; pero no castigado con la formalidad de las leyes, que son vengadoras de los pactos, no de la malicia intrínseca de las acciones.

(Beccaria, De los delitos y las penas, Cap. XXIX)

\section{El origen de la pena privativa de libertad}

El encarcelamiento como sanción penal es un fenómeno histórico relativamente reciente, pero el encierro por orden de autoridad tiene un pasado milenario. ${ }^{1}$ Desde la baja edad media hasta la era moderna operó fundamentalmente como mecanismo de aseguramiento personal, de detención o custodia preventiva ${ }^{2}$ de los sospechosos o condenados por delitos, a la espera durante meses o años del juicio o de la ejecución de la pena de muerte, el destierro u otras penas corporales. ${ }^{3}$ Solo a fines del siglo XVI y albores del XVII, y de la mano con las penas de galeras y de deportación a las colonias de ultramar, ${ }^{4}$ la cárcel comienza a adquirir

\footnotetext{
* Deseo expresar mis agradecimientos al Prof. José Luis Guzmán Dalbora, cuyas lúcidas observaciones me permitieron mejorar algunas deficiencias del texto original y enriquecer el contenido de este trabajo. Asimismo, agradezco el comentario del Prof. Juan Pablo Mañalich y las observaciones realizadas por los académicos y amigos que participaron en el seminario de discusión llevado a cabo el 30 de junio de 2017 en la Sala de Facultad de la Escuela de Derecho de la Universidad de Chile.

${ }^{1}$ Un recuento breve y bien documentado de la historia y antecedentes de la pena privativa de libertad, puede verse en: GUZMAN DALBORA, José Luis, La pena y la extinción de la responsabilidad penal, Santiago: LegalPublishing, 2008, pp. 165-184. Para un lato desarrollo del tema, vid. RUSCHE, Georg y KIRCHHEIMER, Otto, Pena y estructura social, Trad. GARCÍA MÉNDEZ, Emilio, Bogotá: Temis, 1984; FOUCAULT, Michel, Vigilar y castigar, Trad. GARZÓN, Aurelio, Buenos Aires: Siglo XXI, 2002.

${ }^{2}$ BECCARIA se refiere a ella en esos términos cuando denuncia la injusticia del sistema criminal de su época, "porque se arrojan confundidos en una misma caverna los acusados y los convictos; porque la prisión es más bien un castigo que una custodia del reo" (Tratado de los delitos y de las penas, Capítulo XXIX, Madrid: Universidad Carlos III, 2015, p. 63).

${ }^{3}$ RUSCHE/KIRCHHEIMER, Pena y estructura social, cit. nota $\mathrm{n}^{\circ} 1$, p. 23, quienes afirman que "la totalidad del sistema [era] una expresión de sadismo en el que los efectos disuasivos del carácter público de las penas ocupaban un segundo plano." Estos autores relatan "sobre ejecuciones practicadas con cuchillo, hacha y espada, cabezas golpeadas con maderas o cortadas con arados, gente enterrada viva o dejada morir de hambre, clavos martillados en la cabeza, ojos, hombros y rodillas, estrangulaciones y asfixiamientos, desangramientos y desvisceraciones, estiramientos del cuerpo hasta la descuartización, torturas sobre la rueda y con tenazas al rojo vivo, cortes del cuerpo en distintas piezas o aserramientos de él con instrumentos de hierro y madera, quemas en la pira y muchas otras formas más de crueldad elaborada" (pp. 72ss.).

${ }^{4}$ La pena de esclavitud en galeras surge y se mantiene hasta el s. XVIII por consideraciones económicas o bélicas, pero no penales, y a pesar del terrible destino que sufrían los convictos se la consideró "más humana" que las prácticas penales precedentes. Lo mismo ocurrió con la pena de deportación, que consistió en embarcar a los convictos hacia el nuevo mundo por las necesidades militares y de trabajo que demandaba la expansión colonial; la servidumbre de trabajo forzado es la precursora de la cárcel. Según Rusche y Kirchheimer, estos cambios no fueron el resultado de consideraciones humanitarias, sino de un cierto desarrollo económico que revelaba el valor potencial de una masa de material humano a entera disposición del aparato administrativo. La fuerza de trabajo que el Estado podía controlar mejor estaba compuesta de personas que ejercían profesiones
} 
HORVITZ, María Inés. "La insostenible situación de la ejecución de las penas privativas de libertad: ¿vigencia del Estado de derecho o estado de naturaleza?”.

relevancia -aunque todavía no como pena- por su gran funcionalidad para satisfacer los requerimientos del naciente sistema económico de orden capitalista, esto es, mano de obra barata y el disciplinamiento de marginales y delincuentes a través del trabajo forzado. ${ }^{5}$

El severo deterioro de las condiciones de vida de las clases sociales más bajas determinó el incremento de la delincuencia y la utilización del sistema penal para reprimir brutalmente a los empobrecidos de estatus social inferior. ${ }^{6}$ En razón de una legislación composicional orientada deliberadamente contra las clases inferiores, los prisioneros más ricos podían pagar las penas pecuniarias o comprar condiciones de existencia tolerables, mientras que los pertenecientes a las clases más bajas no salían de un auténtico círculo vicioso: eran encarcelados cuando no satisfacían las penas pecuniarias, pero tampoco podían abandonar la prisión, por carecer de dinero para pagar el precio de permanencia y mantenimiento a los carceleros, quienes encontraron en ello una fuente de enriquecimiento personal. ${ }^{7} \mathrm{El}$ aumento del encarcelamiento, confundida con las penas corporales e infamantes, se debió asimismo a la necesidad de un tratamiento diferenciado entre clases sociales. La reclusión en una casa de corrección o en un hôpital era frecuentemente utilizada como una forma de evitar a los miembros de las clases privilegiadas la humillación de las penas corporales o la esclavitud de las galeras. Este proceso fue acompañado por las prerrogativas soberanas de clemencia y la práctica judicial de la poena extraordinaria, la que permitía a los jueces incrementar o reducir las penas en forma arbitraria. ${ }^{8}$

Las casas correccionales, como la de Bridewell en Londres (1555), los Hôpitaux généraux, en Francia, y las que proliferaron en Holanda a fines del siglo XVI (Rasphuis, Spinnhuis, Zuchthuis), se forjaron en una filosofía disciplinaria conductista y moralista puritana, con fuerte influencia del calvinismo y del catolicismo, ${ }^{9}$ orientada a la adquisición de hábitos

ilegales, como mendigos y prostitutas, así como de otras tradicional o jurídicamente sujetas a la protección y a la asistencia de la autoridad pública: viudas, dementes y huérfanos (Pena y estructura social, cit. nota $\mathrm{n}^{\circ} 1$, 25ss., pp. 61ss.).

${ }^{5}$ FOUCAULT, Vigilar y castigar, cit. nota ${ }^{\circ} 1$, pp. 141-142.

${ }^{6}$ En la etapa de transición al capitalismo, entre los siglos XIV y XV, "el constante incremento de los delitos entre los grupos proletarios más golpeados por la pobreza, obligó a las clases dominantes a buscar nuevos métodos que hicieran más efectiva la administración de la justicia criminal.” El sistema penal mantiene su régimen dual de penas corporales y pecuniarias, pero la selección de unas u otras se hacía atendiendo a la clase social del condenado. La propia cualidad de "criminal” del acto era determinada por el estatus del responsable del hecho: este era tratado con mucho más rigor si carecía de propiedades o pertenecía a las clases sociales inferiores. Como la mayoría de los infractores eran miembros de las clases sociales inferiores, la palabra villano originalmente adoptada para designar a los miembros de una determinada clase social, se convirtió en un criterio de inferioridad moral. "La pena pecuniaria se trasforma, de una compensación debida a la parte afectada, en un método de enriquecimiento de jueces y funcionarios de la administración de justicia; en la práctica ella estaba reservada a los ricos, del mismo modo que las penas corporales se convierten en la forma punitiva aplicada por excelencia a los pobres." (RUSCHE/KIRCHHEIMER, Pena y estructura social, cit. nota ${ }^{\circ} 1$, pp. 10ss., esp. $15,17)$.

${ }^{7}$ RUSCHE/KIRCHHEIMER, Pena y estructura social, cit. nota ${ }^{\circ} 1$, pp. 72-73.

${ }^{8}$ RUSCHE/KIRCHHEIMER, Pena y estructura social, cit. nota $n^{\circ} 1$, pp. 76-77.

${ }^{9}$ Es interesante comprobar cómo la ética protestante de la burguesía promovió la realización de grandes empresas comerciales y la acumulación de capital aunque sin inhibir los "impulsos de adquisición", los que podían ser justificados ante las clases inferiores por la vía de la renuncia personal y la corrección en el empleo de la riqueza; la caridad asume entonces valor moral frente al éxito material (cfr. RUSCHE/KIRCHHEIMER, Pena y estructura social, cit. nota $\mathrm{n}^{\circ} 1$, pp. 38 ss.). 
Polít. crim. Vol. 13, N²6 (Diciembre 2018) Art. 7, pp. 904-951.

[http://www.politicacriminal.cl/Vol_13/n_26/Vol13N26A7.pdf]

laborales bajo la premisa moral de que el ocio y la vagancia conducen necesariamente al delito, para de este modo utilizar a los internos como fuerza de trabajo.

"Su objetivo principal consistía en trasformar en socialmente útil la mano de obra díscola. Siendo obligados a trabajar dentro de la institución, los prisioneros adquirían hábitos laborales al mismo tiempo que recibían un adiestramiento profesional, a fin de que una vez en libertad se incorporaran voluntariamente al mercado de trabajo. Mendigos, vagabundos, prostitutas y ladrones constituían la población habitual de esta institución, en la que al comienzo solo aquellos condenados por pequeños delitos fueron aceptados; más tarde, sin embargo, arribaron flagelados y marcados, así como sentenciados a largos períodos." 10

El sistema carcelario moderno fue la consecuencia lógica de las casas de corrección y de las transformaciones sociales que originó el mercantilismo y la revolución industrial, pero la legitimación teórica de la prisión fue tarea del Iluminismo. La oposición política y filosófica al absolutismo condenó la justicia penal pre-revolucionaria por el gran poder discrecional de decisión de los jueces, la vaguedad e imprecisión de las formulaciones legales en la configuración de los presupuestos de la punibilidad y la brutalidad de la ejecución de la pena de muerte, aunque consideraba la pena necesaria para mantener las leyes que los hombres se dan para evitar el estado de naturaleza, pero siempre que fuera de absoluta necesidad para la conservación del pacto social. ${ }^{11} \mathrm{Al}$ igual que otros filósofos ilustrados, Beccaria promovió las virtudes de penas como la esclavitud por sobre las atribuidas a la pena de muerte u otros suplicios sobre el cuerpo del condenado, con argumentos preventivos de utilidad social que se correspondían con su planteamiento sobre el fin de las penas.

"El fin, pues, no es otro que impedir al reo causar nuevos daños a sus ciudadanos y retraher a los demás de la comisión de otros iguales. Luego deberán ser escogidas aquellas penas y aquel método de imponerlas que, guardada la proporción, hagan una impresión más eficaz y más durable sobre los ánimos de hombres, y la menos dolorosa sobre el cuerpo del reo."12

La pena de muerte no cumple con tales requisitos debido a su carácter efímero e instantáneo $\mathrm{y}$, por consiguiente, carece de idoneidad para prevenir generalmente los delitos.

"No es lo intenso de la pena, sino su extensión, lo que produce mayor efecto sobre el ánimo de los hombres; porque a nuestra sensibilidad mueven con más facilidad y permanencia las continuas, aunque pequeñas impresiones, que una u otra pasajera, y poco durable, aunque fuerte. El imperio de la costumbre es universal en todo ente sensible, y como por su enseñanza el hombre habla y camina, y provee a sus necesidades, así las ideas morales no se imprimen en la imaginación sin durables y repetidas percusiones." 13

\footnotetext{
${ }^{10}$ RUSCHE/KIRCHHEIMER, Pena y estructura social, cit. nota $n^{\circ} 1$, p. 48.

${ }^{11}$ BECCARIA escribe, al referirse al derecho de castigar del soberano, que: "[t]oda pena, dice el gran Montesquieu, que no se deriva de la absoluta necesidad, es tiránica (...)"(Tratado, cit. nota ${ }^{\circ} 2$, cap. II, p. 19)

${ }^{12}$ BECCARIA, Tratado, cit. nota ${ }^{\circ} 2$, cap. XII, p. 34.

${ }^{13}$ BECCARIA, Tratado, cit. nota n², capítulo XXVIII, pp. 57-58.
} 
HORVITZ, María Inés. "La insostenible situación de la ejecución de las penas privativas de libertad: ¿vigencia del Estado de derecho o estado de naturaleza?".

Lo que importa, entonces, es la representación eficaz y duradera de la pena, no su realidad corporal; por ello resulta inútil el brutal, pero transitorio, despliegue de los patíbulos. Para Beccaria, la pena más eficiente es la esclavitud a perpetuidad, porque el dolor que ocasiona a quien la padece se divide en tantas fracciones como instantes le restan de vida, pero para quien se representa los sufrimientos de los esclavos, "todos los instantes de la esclavitud se contraen a una representación que se vuelve más espantosa que la idea de la muerte."

"No es el freno más fuerte contra los delitos el espectáculo momentáneo, aunque terrible, de la muerte de un malhechor, sino el largo y dilatado ejemplo de un hombre que, convertido en bestia de servicio y privado de libertad, recompensa con sus fatigas aquella sociedad que ha ofendido. Es eficaz, porque con la vista continua de este ejemplo resuena incesantemente alrededor de nosotros mismos el eco de esta sentencia: yo también seré reducido a tan dilatada y miserable condición, si cometiere semejantes delitos."14

Beccaria abogó por la abolición de la pena de muerte proponiendo su sustitución por penas consideradas bajo los parámetros sociales y culturales de su época más benignas, como la esclavitud perpetua más que la prisión. ${ }^{15}$ Su ideario tuvo importante influencia en algunos de los principales actores políticos de la revolución francesa y en los debates parlamentarios en torno a la redacción del Código Penal francés de 1791, particularmente en la fallida propuesta de abolición de la pena de muerte. ${ }^{16}$

Ya en el siglo XVIII había decaído, por razones técnicas y económicas, la pena de galeras ${ }^{17}$ así como también la pena de deportación a las colonias, ${ }^{18}$ pero era común encontrar instituciones cerradas cumpliendo variadas funciones, tales como de orfanato, manicomio, centro de atención de la infancia, de ciegos, sordos y mudos, y de colonia penal. ${ }^{19} \mathrm{La}$ detención en las antiguas casas de corrección o en cárceles comenzó paulatinamente a constituirse en una pena sustitutiva de las penas corporales y de muerte, predominando a fines del siglo XVIII en condiciones misérrimas de vida e higiene debido al hacinamiento, según fueran célebremente descritas por John Howard en 1777. ${ }^{20}$ El incremento de la población y la incapacidad de la producción agrícola para satisfacer la demanda laboral

\footnotetext{
${ }^{14}$ BECCARIA, Tratado, cit. nota $\mathrm{n}^{\circ} 2$, cap. XXVIII, p. 58.

${ }^{15}$ A la prisión dedica el capítulo XXIX de su tratado, y se refiere a ella como una "pena que por necesidad debe, a diferencia de las demás, preceder a la declaración del delito (...)", esto es, como custodia de sospechosos de crímenes a la espera del juicio o la sentencia. Su crítica se orienta a la arbitrariedad en su empleo, en tanto los jueces podían disponerla mediante decreto con cualquier pretexto; a la indeterminación de su duración y a las pésimas condiciones de las cárceles. Sobre la humanidad como idea del derecho y como ideal cultural, vid. GUZMAN DALBORA, José Luis, “Justicia penal y principio de humanidad”, Gaceta Jurídica nº 298 (2005), pp. 36ss.

${ }_{16}$ Vid. la traducción del Código Penal francés de 1791, con detalles sobre sus antecedentes y la discusión parlamentaria en: GUZMAN DALBORA, José Luis, "Código Penal francés de 1791. Traducción y nota introductoria", Revista de Derecho Penal y Criminología ${ }^{\circ} 1$, $3^{\mathrm{a}}$ época (2009), pp. 481-517; TABET, Xavier, "Beccaria, la peine de mort et la Révolution Française", Laboratoire Italien. Politique et société, n 9 (2009), pp. 51ss.

${ }^{17}$ RUSCHE/KIRCHHEIMER, Pena y estructura social, cit. nota ${ }^{\circ} 1$, pp. $65 \mathrm{ss}$.

${ }^{18}$ RUSCHE/KIRCHHEIMER, Pena y estructura social, cit. nota ${ }^{\circ} 1$, pp. $71 \mathrm{ss}$.

${ }^{19}$ Como en las Casas de Pforzheim o Leipzig, o el Instituto de Ludwigsburg; cfr. RUSCHE y KIRCHHEIMER, Pena y estructura social, cit. nota ${ }^{\circ} 1$, pp. 75-76.

${ }^{20}$ HOWARD, John, State of the prison in England and Wales, with preliminary observations and an account of some foreign prisons, New York: Cambridge University Press, 2013.
} 
determinaron el éxodo masivo desde el campo hacia las ciudades, mientras en éstas se expandían las fábricas y la mecanización de la producción industrial en detrimento del trabajo manual y artesanal. El mercado laboral se saturó rápidamente generando un creciente desempleo y la constante reducción de los salarios; el resultado fue la acelerada pauperización de las clases bajas, el aumento de la criminalidad contra la propiedad y la intensificación en el recurso a la cárcel, aunque siempre distinguiéndose según la clase social del condenado. ${ }^{21} \mathrm{~A}$ diferencia de las casas de corrección, las cárceles no eran económicamente rentables: cada vez era más difícil la obtención de márgenes razonables de lucro y más bien aumentaba la probabilidad de pérdidas, sumándose a ello los conflictos con los trabajadores libres por la competencia en el mercado. La cárcel se convirtió en un lugar de tortura a través del trabajo repetitivo, inútil y extenuante, pues ella debía contener una cierta cantidad de dolor y privaciones para la conservación de su carácter de castigo y los consiguientes efectos intimidatorios. ${ }^{22}$ Solo la expansión industrial operada durante el siglo XIX y principios del XX permitió una mejor absorción de la fuerza de trabajo, periodo en el que florecen los planteamientos preventivos que ponen énfasis en el delito como fenómeno social y la pena como un medio útil de disuasión, de reforma de los condenados y de defensa de la sociedad. ${ }^{23}$ La cárcel tendría un papel protagónico de allí en adelante en la satisfacción de estos fines.

La consolidación del encierro como pena trajo consigo el desarrollo de aquello que suele denominarse como "lo carcelario", esto es, un entramado institucional burocrático de vigilancia y castigo abastecido de profesionales y técnicos abocados al tratamiento del desviado, amén de los corolarios post-penitenciarios y sus coerciones implícitas. ${ }^{24}$ La pena de prisión invadió todos los intersticios de la vida de los condenado transformando a la cárcel en una institución totalizadora. ${ }^{25}$ Tal es el origen de la desproporción de los males que irroga al sujeto en relación con los daños del delito, y que desde un punto de vista retributivo la constituyen en un castigo exorbitante. ${ }^{26} \mathrm{Y}$ tal balance no solo abarca las afectaciones de aquellos derechos que no debiesen ser alcanzados por la pena y las deplorables condiciones del encierro, sino también los abusos en el ejercicio del poder disciplinario de la administración penitenciaria. En efecto, así como la cárcel naturaliza todo lo que hay de

\footnotetext{
${ }^{21}$ RUSCHE/KIRCHHEIMER, Pena y estructura social, cit. nota $\mathrm{n}^{\circ} 1$, pp. $107 \mathrm{ss} ., 120 \mathrm{ss}$.

${ }^{22}$ RUSCHE/KIRCHHEIMER, Pena y estructura social, cit. nota $\mathrm{n}^{\circ} 1$, pp. $132 \mathrm{ss}$.

${ }^{23}$ RUSCHE/KIRCHHEIMER, Pena y estructura social, cit. nota $\mathrm{n}^{\circ} 1$, pp. $173 \mathrm{ss}$.

${ }^{24}$ Nos referimos a los efectos criminógenos de la prisión y sus marcas estigmatizantes, que hacen de la reincidencia una profecía auto-cumplida. Cfr. FOUCAULT, Vigilar y castigar, cit. nota n², pp. 306ss.

${ }^{25}$ GOFFMAN, Erving, Internados: ensayo sobre la situación social de los enfermos mentales, Buenos Aires: Amorrortu Editores, 1972. Aunque ilustra el caso de las instituciones psiquiátricas, Goffman extrae las características fundamentales de cualquier institución total, entendida como el lugar de residencia y trabajo donde un gran número de individuos en igual situación, aislados de la sociedad por un considerable periodo de tiempo comparten en su encierro una rutina diaria administrada formalmente y cuya función específica es la vigilancia: "ver que todos (los internos) hagan lo que se les ha dicho claramente que se exige de ellos" (pp. 17ss, p. 20).

${ }^{26}$ FOUCAULT, Vigilar y castigar, cit. nota $\mathrm{n}^{\circ} 2$, p. 308. Beccaria anticipaba este fenómeno - deseado por su utilidad preventiva - al referirse a la esclavitud: "[s]i se me dijese que la esclavitud perpetua es tan dolorosa, y por tanto igualmente cruel que la muerte, responderé que sumando todos los movimientos infelices de la esclavitud lo será aún más; pero estos se reparten sobre toda la vida, y aquella ejercita toda su fuerza en un momento; y en esto se halla la ventaja de la pena de esclavitud, que atemoriza más a quien la ve que a quien la sufre; porque el primero considera todo el conjunto de momentos infelices, y el segundo está distraído de la infelicidad del momento futuro con la del presente." (Tratado, cit. nota $n^{\circ} 2$, cap. XXVIII, p. 59).
} 
HORVITZ, María Inés. "La insostenible situación de la ejecución de las penas privativas de libertad: ¿vigencia del Estado de derecho o estado de naturaleza?".

inhumano en la ejecución de la pena privativa de libertad, asimismo legaliza los excesos disciplinarios, "borrando lo que puede haber de violento en el uno y de arbitrario en el otro, atenuando los efectos de rebelión que ambos pueden suscitar, haciendo por consiguiente inútiles su exasperación y su encarnizamiento, haciendo circular de uno a otro los mismos métodos mecánicos y discretos $(\ldots){ }^{\prime 2}{ }^{27}$

La expansión del discurso de los derechos humanos después de la segunda guerra mundial y los límites impuestos, a través de instrumentos internacionales, en el trato a las personas privadas de libertad fue contribuyendo a mejorar la situación jurídica y fáctica de los reclusos en Europa. Más adelante nos referiremos a los hitos fundamentales de tal experiencia en Alemania y España en la década de los 70 y 80 . Sin embargo, y a pesar de tener la misma tradición jurídica de los países citados, Chile ha permanecido inmune al cambio, a pesar que a comienzos de la década de los 90, durante el proceso de transición democrática, surgiera cierta preocupación por el problema carcelario, aunque no precisamente guiada por afanes humanizadores. ${ }^{28}$ Como intentaremos mostrar, perviven en nuestra cultura jurídica ciertos dispositivos autoritarios heredados del antiguo régimen que han bloqueado el tratamiento de los reclusos como verdaderos sujetos titulares de derechos, pese al reconocimiento formal del derecho interno. La inercia conservadora unida a las políticas de ley y orden dictadas por la ideología de la inseguridad ciudadana, han permitido al Estado chileno mantener el statu quo o exacerbarlo, sin hacer más que concesiones semánticas en el nivel reglamentario. ${ }^{29}$ Desafortunadamente, la doctrina penal ha contribuido a este estado de cosas y solo se atisba algún cambio en el quehacer de los tribunales, de todo lo cual daremos cuenta más adelante.

La cárcel no solo simboliza el lugar institucional en cuyo seno se produce fácticamente el encierro de ciertos individuos condenados penalmente, sino también designa el logos bajo el cual se elabora y reelabora una racionalidad que justifica, explícita o implícitamente, todos sus excesos. En este trabajo se pretende indagar en los discursos de verdad y legitimación que han permitido conservar el tratamiento objetivante de los condenados a penas de prisión. En nuestra opinión, existen diversos soportes ideológicos de origen autoritario que permean la doctrina y la jurisprudencia, y que permiten al legislador omitir la regulación de todo lo que concierne a la ejecución de las penas privativas de libertad. Uno de ellos ha sido la teoría de las relaciones de sujeción (poder) especial, de origen medioeval pero elaborada por la doctrina del siglo XVIII en el continente europeo, a partir de una concepción administrativista monárquica de las relaciones entre Estado y súbdito, y que permitió excluir de su ámbito las garantías de reserva legal y de jurisdiccionalidad.

Este planteamiento tuvo, y tiene aún en nuestro país, un papel relevante en la legislación penal decimonónica, que apenas contenía disposiciones legales referidas a la ejecución de la pena, limitándose a efectuar remisiones a la potestad reglamentaria. Como apunta Guzmán Dalbora, "[n]o son en absoluto casuales el laconismo de los Códigos de la época en orden a lo abarcado por estas penas, ni sus frecuentes remisiones a reglamentos u ordenanzas

\footnotetext{
${ }^{27}$ Foucault, Vigilar y castigar, cit. nota ${ }^{\circ} 2$, pp. 309-310.

${ }^{28}$ Como consecuencia de una serie de fugas y motines en distintos recintos penales ocurridas en 1991, la Cámara Baja creó una comisión destinada a estudiar la situación del sistema penitenciario, pero que no dio lugar a reforma legal alguna. Cfr. RIEGO, Cristián, "La crisis penitenciaria y el informe de la Cámara de Diputados" en BUSTOS, Juan, et.al., Acerca de la cárcel. Cuadernos de Análisis Jurídico n 24 (1993), pp. 65ss.

${ }^{29} \mathrm{Vid}$. infra apartado 2.1 .
} 
confiándoles el gobierno de las cárceles, pero también los castigos disciplinarios, las condiciones del trabajo de los presos, sus relaciones con familiares y allegados, los socorros (...), ${ }^{30}$ entre otras materias sensibles para sus derechos. El Código Penal chileno es un reflejo fiel de esta concepción, mantenida intacta por casi 150 años, ${ }^{31}$ que permitió la colonización "administrativa" de la ejecución de la pena privativa de libertad y su total desvinculación del sentido y finalidad de su imposición en la sentencia judicial. También tiene resabios monárquicos y coloniales, aunque traspasada a la naciente república, la privación de derechos políticos a las personas condenadas a penas aflictivas que, en nuestro ordenamiento constitucional, se remonta a la Carta de $1822,{ }^{32}$ que a su vez tuvo por modelo la Constitución de Cádiz de $1812,{ }^{33}$ planteamiento que ya no resulta legítimo en el contexto de un Estado democrático de derecho. Las normas y tratados internacionales de derechos humanos vigentes en el ordenamiento jurídico nacional imponen al Estado chileno una reforma sustantiva en la materia.

\section{Ejecución de las penas privativas de libertad: el predominio de la concepción administrativista. Razones de tal orientación.}

La propia doctrina nacional está de acuerdo en atribuir carácter esencialmente administrativo a la ejecución de las penas privativas de libertad, a la que se denomina comúnmente "actividad penitenciaria". ${ }^{34}$ En tal sentido, Cordero, citando a Otto Mayer, ha señalado que:

"[1]a actividad penitenciaria constituye una función administrativa, la cual se puede definir como el conjunto de actuaciones jurídicas y materiales vinculadas a las personas que integran la población penal, dando lugar a un régimen disciplinario, de beneficios y gestión que constituyen claramente una actuación administrativa." (Ello) "supone la existencia de dos categorías de sujetos: la Administración pública y la población penal. A su vez, entre ellos se van a forjar un conjunto de vínculos o relaciones jurídicas que necesariamente han de estar regidas por normas objetivas pertenecientes al Derecho público, particularmente al Derecho administrativo." 35

\footnotetext{
${ }^{30}$ GUZMAN, La pena, cit. nota $\mathrm{n}^{\circ} 1$, p. 187.
}

31 Todo lo referente al cumplimiento de las penas privativas de libertad ha sido regulado desde 1911, con la dictación del primer Reglamento penitenciario de carácter nacional, a través de disposiciones reglamentarias. Al respecto, vid. LEON. M.A., Sistema carcelario en Chile. Visiones, realidades y proyectos (1812-1916), Santiago: Ediciones de la Dirección de Bibliotecas, Archivos y Museos, Centro de Investigaciones Barros Arana, 1996.

${ }^{32}$ Vid. infra apartado 2.3.

${ }^{33}$ Art. 24 N³ de la Constitución monárquica española de 1812, que disponía la pérdida de la ciudadanía “[p]or sentencia en que se impongan penas aflictivas o infamantes, si no se obtiene rehabilitación." En los mismos términos está redactado el art. $15 \mathrm{~N}^{\circ} 3$ de la Constitución chilena de 1822.

${ }^{34}$ Sobre el estudio de las normas que regulan esta actividad, su origen y mayor o menor autonomía del derecho pena, vid. RIVACOBA, Manuel, Función y aplicación de la pena, Buenos Aires: Depalma, 1993, pp. 122ss.; del mismo, "Objeto, funciones y principios rectores del denominado derecho penitenciario", Revista de Derecho, Consejo de Defensa del Estado, año 1, nº 2, (2000), pp. 117ss.

${ }^{35}$ CORDERO QUINZACARA, Eduardo, "El control de jurisdiccionalidad de la administración penitenciaria", Doctrina Procesal Penal. Informes en Derecho, Defensoría Penal Pública, (2009), p.10-11. Téngase presente que MAYER (1846-1924) publicó sus famosos tomos de Derecho Administrativo alemán en 1895 (t.I) y 1896 (t.II). 
HORVITZ, María Inés. "La insostenible situación de la ejecución de las penas privativas de libertad: ¿vigencia del Estado de derecho o estado de naturaleza?".

No obstante la cita a autores alemanes y españoles para defender el predominio del derecho administrativo en esta materia, ${ }^{36}$ este autor olvida que en esos países rige el principio de legalidad de la actividad penitenciaria y además existe un órgano jurisdiccional con competencia exclusiva sobre la misma, por lo que no resulta posible la equiparación. ${ }^{37}$ En efecto, en Chile no concurren tales circunstancias en el ámbito de la ejecución de las penas privativas de libertad ${ }^{38}$ a pesar que la doctrina nacional sostiene que este principio, consagrado en el artículo $19 \mathrm{~N}^{\circ} 3$ incisos $6^{\circ}$ y $7^{\circ}$ de la Constitución Política, debería abarcar todas las fases de manifestación de la práctica punitiva estatal -conminación, adjudicación y ejecución de las penas y medidas de seguridad-, en tanto ella constituye una potencial fuente de afectación de derechos constitucionales. ${ }^{39}$ Diversos instrumentos internacionales de derechos humanos, así como la jurisprudencia de sus órganos, han ido sentando estándares más exigentes sobre esta materia. ${ }^{40}$ Chile, sin embargo, no solo no ha cumplido con su deber de regular a través de una ley todo lo concerniente a la ejecución penal, sino que tampoco ha cumplido con el principio de estricta jurisdiccionalidad, en tanto no existen tribunales especializados que resuelvan de manera exclusiva o preponderante los conflictos que surgen entre los privados de libertad con la administración penitenciaria o entre los internos entre sí. ${ }^{41}$

${ }^{36}$ Señala que la mayoría de la doctrina administrativista sostiene esta tesis (con citas a SPIEGEL, Ludwig, Derecho Administrativo, Barcelona-Buenos Aires: Editorial Labor, 1933; FLEINER, Fritz, Instituciones de Derecho Administrativo, Barcelona: Editorial Labor, traducción sobre la 8.a ed. del alemán, 1933; GASCÓN y MARÍN, José, Tratado de Derecho Administrativo, $10^{a}$ ed., Madrid: Bernego, 1950; GUAITA MARTORELL, Aurelio, Derecho Administrativo especial, Zaragoza: Librería General, 1960); CANO MATA, Antonio, "Derecho administrativo penitenciario: protección del recluso", Revista de Administración Pública $\mathrm{n}^{\circ} 76$ (1975), pp. 31-61. Nótese que la mayoría de los citados son autores de la primera mitad del siglo XX, cuando aún tenía clara primacía la doctrina de las relaciones de sujeción especial.

${ }^{37}$ Cfr. MORALES, Ana María, WELSCH, Gherman, HURTADO, María Teresa. Estudio comparado sobre tribunales de ejecución de penas, Santiago: Fundación Paz Ciudadana, 2015, pp. 20 ss.

${ }^{38}$ No siendo suficiente la muy exigua y lacónica regulación que hace el Código Penal en su art. 80, propia de la legislación decimonónica (Cfr. GUZMAN, La pena, cit., nota ${ }^{\circ} 1$, p. 187). De la misma opinión, HERNANDEZ, Héctor, "Comentario al artículo 80" en: COUSO, Jaime y HERNANDEZ, Héctor (Dirs.), Código Penal Comentado. Libro Primero (arts. $1^{\circ}$ a 105) Doctrina y Jurisprudencia, Santiago: Abeledo Perrot/UDP, 2011, pp. 686ss.

${ }^{39}$ VALENZUELA, Jonatan, "Estado actual de la reforma al sistema penitenciario en Chile", Revista de Estudios de la Justicia ${ }^{\circ}$ 6, (2005), pp. 191ss., para quien, "[e]l principio de legalidad en este ámbito asegura, pues, el fundamento democrático de las restricciones a los derechos y garantías de los sujetos y el carácter cognoscitivo de las prohibiciones y mandatos punitivos Sin embargo, en el derecho chileno es manifiesta la infracción de la garantía de ejecución legal de las penas en el ordenamiento jurídico chileno, pues no hay un cuerpo normativo con rango de ley que regule todo lo concerniente a la ejecución de las penas y medidas de seguridad..” (p. 199.)

${ }^{40}$ Entre las reglas e instrumentos internacionales de derechos humanos que se relacionan directamente con el sistema penitenciaria las más importantes son: las Reglas Mínimas de las Naciones Unidas para el Tratamiento de los Reclusos, el Conjunto de Principios para la Protección de Todas las Personas Sometidas a Cualquier Forma de Detención o Prisión, Principios Básicos para el Tratamiento de los Reclusos, las Reglas de las Naciones Unidas Mínimas para las sanciones no privativas de libertad (Reglas de Tokio); las Reglas de las Naciones Unidas para el tratamiento de las reclusas y medidas no privativas de la libertad para las mujeres delincuentes (Reglas de Bangkok). En el contexto regional americano, se pueden mencionar los "Principios y Buenas Prácticas sobre la Protección de las Personas Privadas de Libertad en las Américas" aprobados por la Comisión Interamericana de Derechos Humanos de la Organización de los Estados Americanos.

${ }^{41}$ KÜNSEMÜLLER, Carlos, "La judicialización de la ejecución penal", Revista de Derecho, vol. XXVI, sem. I (2005), pp. 113ss; GUZMAN DALBORA, José Luis, "Consideraciones críticas sobre el reglamento penitenciario chileno", en BAIGUN, David; ZAFFARONI, Eugenio; GARCIA-PABLOS, Antonio; PIERANGELI, José (coord.) De las penas. Homenaje al Profesor Isidoro de Benedetti, Caracas: Depalma, 
Como es sabido, esta materia se regula hasta hoy a través de la potestad reglamentaria del Poder Ejecutivo, específicamente a través del Decreto Supremo $N^{\circ}$ 518, del Ministerio de Justicia, de 21 de agosto de 1998, comúnmente denominado Reglamento de Establecimientos Penitenciarios. ${ }^{42}$ El Código Penal y leyes penales especiales regulan aspectos muy generales de la ejecución penitenciaria que no satisfacen los requerimientos de certeza y taxatividad que impone el principio de legalidad. ${ }^{43} \mathrm{Ha}$ habido diferentes propuestas y anteproyectos elaborados para introducir un cuerpo legal que regule de modo orgánico y sistemático todo lo concerniente al cumplimiento de las penas, pero ninguno ha prosperado ${ }^{44}$ a pesar de los

1997, pp. 271ss. Dicho autor expresa “... [si] a esto se agrega, como ulterior elemento de juicio, la total ausencia de un efectivo control jurisdiccional sobre la ejecución de las penas privativas de libertad, no resultará difícil concluir que en este Reglamento se compromete, no teórica, sino realmente, derechos elementales garantizados por la Constitución política del Estado." Si bien la reforma procesal penal confirió competencia a los jueces de garantía para resolver las cuestiones que se susciten durante la ejecución penal, la escueta regulación contenida en el art. 466 del Código Procesal Penal y la ausencia de mecanismos e incentivos para que los jueces cumplan de modo eficiente con esta tarea, ha determinado una escasa incidencia de esta norma en el mejoramiento de la protección jurídica de los internos.

${ }^{42}$ La regulación original estuvo contenida en el D.S. $\mathrm{N}^{\circ} 1771$, de 9.02. 1993. Antes regía el Reglamento Carcelario, Decreto Supremo N 805, del Ministerio de Justicia, de 30 de abril de 1928.

${ }^{43}$ Vid. HORVITZ, María Inés, "Ejecución de las sentencias condenatorias y de las medidas de seguridad”, en: HORVITZ, María Inés y LOPEZ, Julián, Derecho procesal penal, T. II, Santiago: Ed. Jurídica de Chile, 2004, pp. 589ss.

${ }^{44}$ Sobre las vicisitudes de las diferentes iniciativas y anteproyectos de reforma legal de tiempos recientes, cfr. STIPPEL, Jörg, Cárcel, derecho y política, Santiago: LOM Ediciones, 2013, pp. 58ss, 93ss.; también, VALENZUELA, "Estado actual”, cit. nota n 39, pp. 191ss. Más recientemente, en junio de 2009, el Ministerio de Justicia convocó a un consejo intersectorial ("Consejo para la Reforma Penitenciaria”) con el fin de generar una propuesta de política penitenciaria de cara al bicentenario de la República. El resultado fue un documento con recomendaciones (cfr.https://www.cesc.uchile.cl/Informe_CRPenitenciaria.pdf. consultado el 20.12.2017) En él no se propone explícitamente una ley- que regule toda la actividad penitenciaria, sino una "nueva institucionalidad" a cargo de la misma. 
HORVITZ, María Inés. "La insostenible situación de la ejecución de las penas privativas de libertad: ¿vigencia del Estado de derecho o estado de naturaleza?”.

continuos reclamos planteados por académicos, ${ }^{45}$ organizaciones de derechos humanos, ${ }^{46} \mathrm{de}$ la sociedad civil ${ }^{47}$ y miembros del poder judicial, ${ }^{48}$ entre otros.

La ausencia de las garantías penales de reserva legal y de jurisdiccionalidad en la fase de ejecución de las penas privativas de libertad significa, en pocas palabras, dejar entregada la suerte de los reclusos al autocontrol y a la discrecionalidad del órgano público a cargo de ella, ${ }^{49}$ pues resulta inconcebible el reconocimiento de derechos subjetivos públicos a cualquier persona si no se dispone de mecanismos jurisdiccionales efectivos para su tutela para el caso de afectación o abuso que provenga de la propia administración . Como se podrá apreciar más adelante, aunque ciertos tribunales tienen competencia y atribuciones para pronunciarse acerca de los reclamos de los reclusos en el ámbito de los derechos constitucionales que no deberían ser afectados por la irrogación de la pena, la práctica

${ }^{45}$ CARNEVALI, Raúl y MALDONADO, Francisco, "El tratamiento penitenciario en Chile. Especial atención a problemas de constitucionalidad", Revista Ius et Praxis, año 19, № 2 (2013), p. 408; SEPULVEDA, Eduardo, "El ordenamiento jurídico penitenciario chileno: sus reformas más urgentes", en HORVITZ, María Inés y STIPPEL, Jörg (coords.) Estado de derecho y reformas a la justicia, Santiago: Universidad de Chile [Centro de Estudios de la Justicia], Heidelberg Center para América Latina, California Western School o f Law, GTZ [Proyecto Reforma Judicial], 2005, pp. 121ss.

${ }^{46}$ Cfr. Estudio sobre las condiciones carcelarias en Chile. Diagnóstico del cumplimiento de los estándares internacionales de derechos humanos, Instituto Nacional de Derechos Humanos, 2013, en: http://bibliotecadigital.indh.cl/bitstream/handle/123456789/639/Estudio\%20general?sequence $=4$ [consultado el 20.12.2017], en cuya p. 191 se lee: “[e]s posible afirmar que la situación del derecho a la integridad de las personas privadas de libertad es preocupante dado que las cárceles chilenas son espacios de extrema discrecionalidad y de ausencia de control, donde el uso de la violencia como forma de relacionarse y controlar a la población constituye una práctica arraigada en la cultura institucional. Por eso resulta necesario una vez más llamar la atención sobre la necesidad de contar con una ley de ejecución penal que regule los derechos y deberes de los/as penados/as y en los cuales se establezcan claramente los casos y límites asociados al uso de la fuerza por parte de los/as funcionarios/as. Además, resulta fundamental, en consonancia con recomendaciones efectuadas por otras instancias nacionales, que se establezca la figura del control judicial efectivo con el objeto de contar con una supervisión externa de los actos de la Administración. Sin embargo, mientras no se avance en esa línea, pese a su urgencia, se sugiere que se modifique el Reglamento de Establecimientos Penitenciarios para eliminar, al menos en dicho nivel, los espacios de discrecionalidad de la Administración."

${ }^{47}$ Como las ONG Leasur, 81 Razones (familiares de internos fallecidos en incendio de Cárcel de San Miguel, ocurrido el 8 de diciembre de 2010), Confapreco, Paternitas, entre otras.

${ }^{48}$ Informes de la ex Fiscal Judicial de la Corte Suprema, Mónica Maldonado [2001/2014] Cfr. DAVID, Valeska, "Entrevista a Mónica Maldonado. Las condiciones carcelarias en Chile", en Anuario de Derechos Humanos, $\mathrm{N}^{\circ}$ 6, 2010, pp. 211-222.

${ }^{49}$ En apretada síntesis, RIVACOBA indaga en las razones de la temprana "administrativización" de la ejecución de las penas privativas de libertad, sugiriendo que algunas de ellas estarían vinculadas a su prolongada duración y al necesario requerimiento de resoluciones complementarias, situación que no se avendría con la función judicial sino con la discrecional de la Administración, Función y aplicación, cit. nota $\mathrm{n}^{\circ} 34$, pp. 63-64; GUZMAN, La pena, cit., nota ${ }^{\circ} 1$, p. 187-188. CORDERO (cit. nota ${ }^{\circ} 35$, pp. 14 ss.) opone a las objeciones de arbitrariedad de la administración, el argumento de "que el Derecho administrativo ha ido desarrollando diversas técnicas destinadas a garantizar el control de la discrecionalidad a fin de encauzarla bajo reglas objetivas y precisas. A su vez, en el ámbito disciplinario y de las sanciones administrativas es donde se ha fortalecido con mayor fuerza este punto, al momento de proyectar los principios penales en el orden administrativo, como la legalidad, irretroactividad y culpabilidad. Por último, la posibilidad de obtener por la vía jurisdiccional una revisión de dichos actos es una cuestión bastante asentada en nuestro Derecho y que no marca una diferencia sustancial entre la posición que debe adoptar un juez contencioso-administrativo y un juez de ejecución". Sin embargo, no se hace cargo de que precisamente son tales instituciones garantizadoras las que no existen o solo muy limitadamente en el ámbito penitenciario nacional. 
judicial arroja un saldo negativo en esta materia. ${ }^{50}$ La administrativización de lo carcelario invisibiliza el hecho de que allí se ejecuta la práctica del castigo y, al mismo tiempo, la banaliza.

\section{Como señala Foucault:}

El castigo tenderá, pues, a convertirse en la parte más oculta del proceso penal. Lo cual lleva consigo varias consecuencias, la de que abandona el dominio de la percepción casi cotidiana, para entrar en el de la conciencia abstracta; se pide su eficacia a su fatalidad, no a su intensidad visible; es la certidumbre de ser castigado, y no ya el teatro abominable, lo que debe apartar del crimen; la mecánica ejemplar del castigo cambia sus engranajes. Por ello, la justicia no toma sobre sí públicamente la parte de violencia vinculada a su ejercicio (...). A partir de este momento, el escándalo y la luz se repartirán de modo distinto; es la propia condena la que se supone que marca al delincuente con el signo negativo y unívoco; publicidad, por lo tanto, de los debates y de la sentencia; pero la ejecución misma es como una vergüenza suplementaria que a la justicia le avergüenza imponer al condenado; mantiénese, pues, a distancia, tendiendo siempre a confiarla a otros, y bajo secreto. Es feo ser digno de castigo, pero poco glorioso castigar. De ahí ese doble sistema de protección que la justicia ha establecido entre ella y el castigo que impone. La ejecución de la pena tiende a convertirse en un sector autónomo, un mecanismo administrativo del cual descarga a la justicia; ésta se libera de su sorda desazón por un escamoteo burocrático de la pena (...). ${ }^{51}$

\subsection{El paradigma de las relaciones de sujeción especial}

El 14 de marzo de 1972, el Tribunal Constitucional (TC) alemán acogió un requerimiento de inconstitucionalidad de un precepto reglamentario que autorizaba a los encargados de los establecimientos penitenciarios a controlar (e incautar) la correspondencia de los internos en determinados supuestos, entre los cuales se hallaban los escritos que contuvieran expresiones insultantes o que afectaran la decencia, o declaraciones aparentemente falsas o delictivas o sobre las relaciones del recinto carcelario, en tanto no se refirieran personalmente al recluso. ${ }^{52}$ El alto tribunal señaló en forma expresa que:

También los derechos fundamentales de los reclusos solo pueden ser afectados a través de una ley o con ocasión de ella. La Ley Fundamental, en sus artículos 104 párrafos 1 y 2 y 2 párrafo 2 incisos 2 y 3, establece la posibilidad de una privación de libertad, limitada o no temporalmente, en virtud de una sentencia penal judicial en aplicación de una ley penal y atendiendo las correspondientes disposiciones procesales. Por el contrario, no contiene (...) ninguna declaración fundamental sobre la forma y modo en que debe ejecutarse la pena privativa de libertad. En tanto se trate de la restricción de derechos fundamentales son decisivas las normas constitucionales afectadas, pues esto solo es permitido a través de una ley o con ocasión de ella (...). La conclusión obvia de que el legislador está obligado, en razón de estos fundamentos, a dictar la correspondiente ley en el ámbito de la ejecución penal - el que hasta ahora está regulado

\footnotetext{
${ }^{50}$ Vid. infra apartado 3.

${ }^{51}$ FOUCAULT, Vigilar y castigar, cit. nota ${ }^{\circ} 1$, pp.17-18.

52 Parágrafo 155, Dienst-und Vollzugsordnung (DVollzO), de diciembre de 1961.
} 
HORVITZ, María Inés. "La insostenible situación de la ejecución de las penas privativas de libertad: ¿vigencia del Estado de derecho o estado de naturaleza?”.

predominantemente por disposiciones administrativas- no fue planteada por la doctrina ni por la jurisprudencia después de la entrada en vigor de la Ley Fundamental. Más bien se recurrió a la figura jurídica de las "relaciones de sujeción especial", entendiéndola como una restricción independiente e implícita de los derechos fundamentales de los reclusos; una ley de ejecución penal no se consideró constitucionalmente requerida (...).

Este planteamiento retrospectivo se realiza para clarificar que la configuración tradicional de la ejecución penal como una "relación especial de sujeción" permitió relativizar los derechos fundamentales de los reclusos con insoportable incertidumbre. La Ley Fundamental es un orden vinculado a valores, que reconoce la protección de la libertad y la dignidad humanas como el fin superior de todo el derecho; su concepción de hombre no es, sin embargo, la de un individuo con autodominio sino de uno cuya personalidad se encuentra situada y comprometida de diversas formas con la sociedad (...). En el art. 1 párrafo 3 de la Ley Fundamental se establece que los derechos fundamentales son inmediatamente vinculantes para el legislador, el poder ejecutivo y la judicatura. Este amplio vínculo del poder estatal es contrariado cuando durante la ejecución penal los derechos fundamentales pueden ser limitados o afectados de forma arbitraria o discrecional (...). ${ }^{53}$

El TC reconoce explícitamente y por primera vez que en el ámbito de la ordenación del régimen penitenciario debe aplicarse estrictamente el principio de legalidad. En efecto, deja asentado que los derechos y libertades fundamentales de los internos sólo podrán ser limitados por medio de una ley o sobre la base de una ley y siempre que sea imprescindible para la consecución de alguno de los fines cubiertos por el orden valorativo de la Constitución y en la forma prevista por ella. Al no existir una ley que regule los derechos y libertades de los presos, las disposiciones reglamentarias de la Administración penitenciaria no pueden por sí solas restringir los derechos fundamentales de los presos, como hasta entonces venía sucediendo. La importancia de este fallo es innegable, en tanto no existe publicación alguna sobre este tema que no destaque su impacto en la protección de los derechos de los reclusos, con distintas aproximaciones. ${ }^{54}$

En efecto, hasta la dictación de esta sentencia, pronunciada hace más de 40 años, la doctrina de las "relaciones de sujeción especial" 55 era la más empleada para fundar la restricción de los derechos fundamentales de las personas que cumplen penas privativas de libertad, sin perjuicio de aplicarla también a otros ámbitos. ${ }^{56}$ No obstante, hubo autores que

\footnotetext{
${ }^{53}$ Beschluss des Zweiten Senats vom 14.03.1972, 2 BvR 41/71 (la traducción es nuestra).

${ }^{54}$ En lengua española, vid. RIVERA BEIRAS, Iñaki, La cuestión carcelaria. Historia, epistemología, derecho y política penitenciaria, Buenos Aires: Editores del Puerto, 2006, pp. 516-520, y bibliografía citada. En alemán, cfr. FEEST, Johannes, LESTING, Wolfgang, SELLING, Peter. Totale Institution und Rechtsschutz- Eine Untersuchung zum Rechtsschutz im Strafvollzug, Opladen: Westdeutscher Verlag, 1997; GÜNTHER, Klaus, "Die Konstitutionalisierung des Strafvollzuges durch das Bundesverfassungsgericht. Ein Beispiel für die Fragilität der Verfassungsdynamik", Kritische Vierteljahresschrift für Gesetzgebung und Rechtswissenschaft, vol. 83, nr. 3-4, (2000), pp. 299ss.

${ }^{55}$ La doctrina alemana de derecho administrativo utiliza la expresión "besonderes Gewaltverhältnis" cuya traducción literal sería "relaciones de poder especial". La empleada en el texto es la más difundida en lengua española.

56 Sobre el origen y evolución de esta categoría dogmática en el derecho público, cfr. GALLEGO ANABITARTE, Alfredo, "Las relaciones especiales de sujeción y el principio de legalidad de la Administración", Revista de Administración Pública nº 34 (1961), pp. 11ss.; GARCÍA MACHO, Ricardo, Las
} 
tempranamente manifestaron su rechazo a esta figura jurídica, caracterizándola de enclave autoritario o reminiscencia del estado de policía. ${ }^{57}$ Un caso particular es el de Freudenthal, quien, de forma lúcida y visionaria, ya en 1909 abogaba por la superación de la doctrina de las relaciones de poder especial y por la dictación de una ley de ejecución penal que consagrara una relación jurídico-pública del preso con el Estado, sentando las bases de la misma. ${ }^{58}$

(...) precisamente el Derecho del Estado, que a través del Derecho vigente nos ha conducido a la exigencia de una ley de ejecución, traza también ciertas líneas de orientación para el contenido de esa ley futura. Será su tarea más importante dar cabal forma a la condición de preso como relación jurídica. De esta manera, se elimina en lo factible la discrecionalidad de las autoridades de la ejecución, colocándose en su lugar la voluntad del ordenamiento jurídico.

(...) el Derecho del Estado nos ofrece como fundamental punto de vista el principio siguiente: donde |se trate de establecer derechos y deberes de los individuos —aquí, de los presos-, y no de meras instrucciones de las autoridades de la ejecución, allí también la ley debe dictar preceptos.

La condición de preso, como hemos visto, es una relación jurídica cuyo contenido faculta al Estado para imponer al preso una limitación de la libertad personal. ¡Una limitación de la libertad, nada más!, iy a nadie más que el preso! Será principal tarea de la futura ley poner nítidamente de relieve el carácter jurídico de la condición de preso también en estos dos puntos. En una futura ley de ejecución deberá cobrar expresión más neta que en el Derecho vigente, que las penas privativas de la libertad, en el marco de lo realizable, conducen sólo a limitaciones de la libertad y deben afectar sólo a los condenados a ellas.

El jefe de nuestra ejecución penal en el ministerio prusiano del interior, el Consejero privado Krohne, allí donde trata de la historia de la ejecución, ha descrito esa antigua concepción con estas palabras: en aquellos tiempos pretéritos el condenado estaba, "con su persona y su patrimonio, a incondicional disposición del poder del Estado para alcanzar los fines de la pena".

Nosotros deberemos liberarnos completamente de esa concepción, a favor de la solución que nos da el Estado de Derecho, a saber: en la relación jurídica entre Estado y preso, nada puede ser impuesto a éste que no esté ordenado para él, conforme a la ley, en la

\footnotetext{
relaciones de especial sujeción en la Constitución española, Madrid: Tecnos, 1992; LASAGABASTER, Iñaki, Las relaciones de sujeción especial, Madrid: Civitas, 1994; LÓPEZ BENÍTEZ, Mariano, Naturaleza y presupuestos constitucionales de las relaciones especiales de sujeción, Córdoba: Civitas, 1994.

${ }^{57}$ Vid. ABELEIN, Manfred, "Rechtsstaat und besonderes Gewaltverhältnis", Rechtsschrift für Politik, $\mathrm{n}^{\circ} 3$, vol. 14, (1967), pp. 313ss.

${ }^{58}$ Con el título original Die staatsrechtliche Stellung des Gefangenen (impreso, como folleto, por la Gustav Fischer Verlag, en 1910, y vuelto a publicar en la Zeitschrift für Strafvollzug, 1955, pp. 157 y ss.), su texto fue traducido al castellano por José Luis Guzmán Dalbora, quien hace presente que este representa el discurso pronunciado por el autor el 3 de noviembre de 1909, con motivo de la toma de posesión del cargo de Rector de la Academia de Ciencias Sociales y Mercantiles de Frankfurt a.M., precursora de la Universidad de la misma ciudad y de cuya Facultad de Derecho Freudenthal fue su primer Decano; Cfr. FREUDENTHAL, Berthold, "La posición jurídico-pública del preso", Trad. GUZMÁN DALBORA, José Luis, Revista Peruana de Ciencias Penales, $\mathrm{n}^{\circ} 13$ (2004), pp. 351ss; asimismo, GUZMAN, La pena, cit. nota n 1 , pp. 188-189.
} 
HORVITZ, María Inés. "La insostenible situación de la ejecución de las penas privativas de libertad: ¿vigencia del Estado de derecho o estado de naturaleza?”.

pena judicial privativa de la libertad sobre su, a ser posible, mera ejecución”. Esta es la pauta que el Derecho penal ha recibido, a lo largo del camino, de su suelo materno, del Derecho del Estado. ${ }^{59}$

Elaborada en la primera mitad del siglo XIX, el origen de esta construcción teórica se vincula al estudio y definición de la relación entre los funcionarios públicos y el Estado, caracterizada como una de dependencia, obediencia y subordinación, similar a la que antiguamente existía entre señor y vasallo o entre monarca y súbdito. ${ }^{60}$ Esta concepción de "relación de servicio" del empleado con el Estado tuvo como consecuencia crucial que el funcionario no es visto como sujeto titular de derechos sino tan solo como un "miembro" de la Administración, y por consiguiente, todo su ordenamiento interno carece de relevancia jurídica - el paralelo sería la relación doméstica del particular con sus empleados en la conducción de su negocio o del hogar; dicho en otras palabras, toda la teoría de la función pública es un espacio ausente de derecho (ein rechtsfreier Raum). ${ }^{61}$

El principio de legalidad de la Administración no tiene cabida en el marco de esta teoría, pues aunque se considera que los derechos fundamentales constituyen un caso especial de reserva de ley, estos solo excepcionalmente son vinculados a una relación especial de poder; junto con ello, ningún autor identificó algún bien digno de protección jurídica en este ámbito.$^{62}$ De modo que este planteamiento sirvió para justificar la ausencia o debilitamiento de protecciones jurídicas para quienes se encuentran sometidos a esta relación "cualificada" con los poderes públicos, determinando no solo la impertinencia del principio de legalidad sino, además, de la tutela jurisdiccional. El estatus jurídico del administrado queda reducido al cumplimiento de deberes para la satisfacción de algún interés público y apenas se le reconocen derechos, aunque tampoco están claras las obligaciones. ${ }^{63}$ Paradigmáticamente, dentro de esta categoría están los reclusos o internos de los establecimientos penitenciarios,

${ }^{59}$ El destacado en cursiva es del texto.

${ }^{60}$ LASAGABASTER, Las relaciones, cit. nota $\mathrm{n}^{\circ}$ 56, pp. 30ss; GUZMAN, La pena, cit. nota ${ }^{\circ} 1$, p. $187 \mathrm{ss}$.

${ }^{61}$ ABELEIN, "Rechtsstaat", cit. nota $n^{\circ}$ 57, pp. 314-317, con cita a LABAND (Staatsrecht der Deutschen Reiches, $5^{\mathrm{a}}$ ed., Berlin, 1911). Destaca, sin embargo, que fue OTTO MAYER (Das deutsche Verwaltungsrecht, 2 Aufl., Bd. I, 1914) el autor alemán que más impacto tuvo en el desarrollo de esta teoría, constituyéndose en doctrina dominante hasta 1945. Ya en 1888 señalaba: "Das ganze Verhältnis des Staates zu seinen Untertanen ist ein grosses Gewaltverhältnis. Daraus treten engere Kreise hervor, für welche das Gewaltverhältnis eine besondere, scharfe Ausprägung erhalten hat, besondere Gewaltverhältnisse.” [Toda la relación del Estado con sus súbditos es una gran relación de poder. De allí surgen círculos más estrechos, en los cuales la relación de poder se manifiesta con especial fuerza, las relaciones especiales de poder]. Vid. también, GUZMAN, La pena, cit. nota $\mathrm{n}^{\circ} 1$, pp. 184ss., esp. 188, para quien esta teoría afirma que "no hay entre el preso y el estado un auténtico vínculo jurídico, con derechos y obligaciones recíprocos, sino una situación unilateral de sujeción que impone a aquél el deber de soportar toda clase de restricciones a sus prerrogativas no alcanzadas por la condena, si así lo indican los fines particulares de la organización penitenciaria, cuyas decisiones al respecto escaparían al control jurisdiccional."

${ }^{62}$ ABELEIN, "Rechtsstaat", cit. nota $\mathrm{n}^{\circ}$ 57, pp.317-318; incluso después de la Constitución de Weimar, la doctrina dominante sostenía que los derechos fundamentales solo podían ser considerados como bienes jurídicos en las relaciones generales de poder, no en las especiales, perspectiva que sobrevivió a la II Guerra Mundial; una opinión distinta fue sostenida por Carl Schmitt, para quien los derechos fundamentales estaban por sobre los poderes del Estado, y tenían vigencia tanto en el ámbito de las relaciones generales como especiales de sujeción (p.320).

${ }^{63}$ LASAGABASTER, Las relaciones, cit. nota ${ }^{\circ}{ }^{56}$, pp. 40 ss, quien precisa que el poder especial del Estado no tiene previamente establecidas las obligaciones a las que se somete el afectado, sino que las determina el propio titular del poder (p. 48). 
como también los alumnos de escuelas públicas, los enfermos atendidos en los hospitales públicos o los soldados con la institución militar.

Solo a partir de la sentencia del TC alemán se produce un cambio importante en el contenido de esta tradicional relación de especial sujeción, que se extenderá a los demás casos. ${ }^{64}$ Desde entonces — se concluyó- les serán de aplicación los principios inherentes al Estado de Derecho: el principio de legalidad; el de respeto de los derechos y libertades, cuyas limitaciones sólo se efectuarán por ley, y el relativo al control jurisdiccional de las actuaciones de la Administración respecto de los administrados sometidos a las relaciones de especial sujeción. ${ }^{65}$ La sentencia estableció un plazo para que el legislador dictara una ley de ejecución penitenciaria, ${ }^{66}$ disponiendo sin embargo que durante el periodo de transición serían admisibles ciertas restricciones de los derechos fundamentales de los reclusos "cuando fuera imprescindible para el cumplimiento de la pena o para ejecutarla ordenadamente". En 1975 se creó, junto con los tribunales de ejecución penal, una jurisdicción especializada para el ámbito penitenciario. Las personas privadas de libertad podrían ahora acudir a estos tribunales cuando con ocasión de alguna medida u omisión por parte del establecimiento, se considerasen perjudicados en sus derechos (art. 109, StVollzG, en su tex to de la época).

En España se dio una evolución distinta y paradójica. El 26 de septiembre de 1979 se dictó la Ley Orgánica General Penitenciaria (LOGP), primera ley orgánica tras la promulgación de la Constitución, que consagró el reconocimiento y ejercicio de los derechos fundamentales de los reclusos en términos muy amplios ${ }^{67}$ e introdujo por primera vez en la legislación española la figura del juez de vigilancia penitenciaria para la tutela de tales derechos ${ }^{68}$ aunque la evaluación de su funcionamiento no siempre ha sido positiva. ${ }^{69} \mathrm{El}$

\footnotetext{
${ }^{64}$ Sobre los particulares efectos de la sentencia y la discusión doctrinal en Alemania, cfr. GÜNTHER, "Die Konstitutionalisierung", cit. nota ${ }^{\circ}$ 54, pp. 298ss.; quien señala que, "[e]n lo principal, la ejecución penal ya no valdría más como una relación interna con la Administración, sino como una cuestión pública, que debía ser regulada legalmente a través del Poder Legislativo democrático" (p. 302); en general, vid. LASAGABASTER, Las relaciones, cit. nota $\mathrm{n}^{\circ} 56$, pp. $112 \mathrm{ss}$.

${ }^{65}$ GÜNTHER hace referencia al "largo camino desde las relaciones de sujeción especial al reconocimiento de derechos subjetivos públicos, el que mirado retrospectivamente produce sin embargo una gran sorpresa, pues la situación jurídico-constitucional de los presos en la ejecución penal ha sido históricamente de manifiesta desproporcionalidad con los derechos fundamentales asegurados durante el procedimiento hasta la condena a una pena privativa de libertad" ("Die Konstitutionalisierung”, cit. nota n 54, p. 303).

${ }^{66} \mathrm{El}$ tribunal resolvió darle al legislador un plazo para la elaboración de la respectiva normativa, a saber, hasta la finalización del período legislativo en curso, es decir, hasta fines de 1973. A pesar de ello, el parlamento alemán aprobó, recién a fines del año 1976, la que sería la Ley de Ejecución Penitenciaria (Strafvollzugsgesetz), cuya entrada en vigencia fue el $1^{\circ}$ de enero de 1977 para toda Alemania Federal. Se hace presente que a partir de la reforma federal de 2006 y el traslado de la competencia legislativa de la federación a los estados, cada estado federado ha promulgado su propia ley de ejecución penal.
}

${ }^{67}$ Así, por ejemplo, el art. 3 de la LOGP señala que: "Los internos podrán ejercitar los derechos civiles, políticos, sociales, económicos y culturales, sin exclusión del derecho de sufragio, salvo que fuesen incompatibles con el objeto de su detención o el cumplimiento de la condena."

${ }^{68}$ El art. 76 de la LOGP atribuye al Juez de Vigilancia la tarea de «salvaguardar los derechos de los internos y corregir los abusos y desviaciones que en el cumplimiento de los preceptos del régimen penitenciario puedan producirse».

${ }^{69}$ Así, Rivera efectúa las siguientes apreciaciones generales sobre el órgano jurisdiccional penitenciario: "(...) problemas de dotación orgánica, inexistencia de especialización en los titulares de los Juzgados de Vigilancia Penitenciaria, dificultades para hacer cumplir el principio de inmediación, carencia de normas reguladoras del 
HORVITZ, María Inés. "La insostenible situación de la ejecución de las penas privativas de libertad: ¿vigencia del Estado de derecho o estado de naturaleza?”.

apartado 2 del art. 76, LOGP, regula en detalle las competencias generales del juez de vigilancia penitenciaria. Entre éstas se encuentra la revisión de las decisiones relativas a la clasificación inicial, la aprobación de sanciones de aislamiento y el conocimiento de reclamaciones contra sanciones disciplinarias. Sin embargo, y como veremos seguidamente, ello no impidió que se siguiera utilizando la doctrina de las relaciones especiales de sujeción de forma "inusitada", debido a que el Tribunal Constitucional admitió, en diversas sentencias, su pervivencia en una "zona" de la ejecución penitenciaria. ${ }^{70}$

Nos parece especialmente ilustrativa la sentencia $\mathrm{N}^{\circ} 2 / 1987$, de 21 de enero, que contiene los argumentos paradigmáticos en virtud de los cuales se busca justificar el debilitamiento o menoscabo de la protección jurídica de las personas privadas de libertad. El TC debió pronunciarse respecto de un recurso de amparo interpuesto por un interno recluido en la cárcel de Basauri (Viscaya) en contra de la administración penitenciaria que le aplicó en total 33 días de aislamiento en celda, constitutivas de tres sanciones disciplinarias. ${ }^{71} \mathrm{El}$ recurrente había invocado diversos derechos constitucionales afectados con las medidas, el fin de rehabilitación de las penas ${ }^{72}$ y la vulneración del principio de legalidad, aplicable a delitos, faltas o infracciones administrativas (art. 25.1 Constitución española), entre otras alegaciones. En el fundamento $2^{\circ}$ de su fallo, el TC reconoce la vigencia del principio de reserva de ley en el ámbito penitenciario, como garantía de seguridad jurídica que abarca la formulación precisa de la conducta prohibida a fin que el interno pueda prever las consecuencias de su acción; sin embargo a renglón seguido afirma que tal principio tiene un "alcance diferente" cuando se trata de contravenciones "faltas" en el seno de una relación de sujeción especial".

Sin entrar aquí en el tema más general del alcance de la reserva de Ley en las sanciones administrativas, debe tenerse en cuenta que la referencia a la legislación vigente en el art. 25.1 de la Constitución, tiene un alcance diferente, al menos, en lo que se refiere a la tipificación del ilícito, cuando se trata de la determinación de contravenciones «faltas», en el seno de una relación de sujeción especial, como es la de los internos en establecimientos penitenciarios. En estos casos la reserva de Ley cumple principalmente una función de garantizar la seguridad jurídica, de modo que los internos puedan disponer de informaciones suficientes sobre las normas jurídicas aplicables en un determinado caso, y la norma debe formularse con la suficiente precisión para que el

proceso ante la jurisdicción y falta de participación de los abogados en tales procedimientos (...)"· Dicho autor advierte sobre el riesgo de que el control jurisdiccional de la administración penitenciaria constituya una nueva forma de legitimar a "la institución total a la cual brinda una apariencia garantista" y así contribuir a "la permanencia de la existencia de la prisión como sanción penal por excelencia" (RIVERA, La cuestión carcelaria, cit. nota $\mathrm{n}^{\circ} 54$, p. 622 ).

${ }^{70}$ BACIGALUPO, citado por RIVERA, La cuestión carcelaria, cit. nota ${ }^{\circ} 54$, pp. $528 \mathrm{ss}$.

${ }^{71} \mathrm{El}$ mismo interno había recurrido de amparo ante el TC por una infracción menos grave que la fundante del caso en estudio, el que fue resuelto por sentencia 74/1985, de 18 de junio, la que también hizo referencia genérica a las relaciones de sujeción especial en su fundamento jurídico $2^{\circ}$ : "Es claro que el interno de un centro penitenciario está respecto a la Administración en una relación de sujeción especial de la cual deriva para aquélla una potestad sancionatoria disciplinaria, cuyo ejercicio y límites se regulan en los arts. 104 y siguientes del Reglamento Penitenciario (Real Decreto 1201/1981, de 8 de mayo, y Real Decreto 787/1984, de 28 de marzo, de reforma parcial de aquél)."

${ }^{72}$ Consagrado en el art. 25, apartado 2, primera frase, de la CE: "Las penas privativas de libertad y las medidas de seguridad estarán orientadas hacia la reeducación y reinserción social y no podrán consistir en trabajos forzados." 
interno pueda prever razonablemente las consecuencias que puedan derivar de una determinada conducta. El interno se integra en una institución preexistente y que proyecta su «autoridad» sobre quienes, al margen de su condición común de ciudadanos, adquieren el status específico de individuos sujetos a un poder público que no es el que, con carácter general, existe sobre el común de los ciudadanos. En virtud de esa sujeción especial, y en virtud de la efectividad que entraña ese sometimiento singular al poder público, el ius puniendi no es el genérico del Estado, y en tal medida la propia reserva de Ley pierde parte de su fundamentación material, dado el carácter en cierto modo insuprimible de la potestad reglamentaria, expresiva de la capacidad propia de autoordenación correspondiente, para determinar en concreto las previsiones legislativas abstractas sobre las conductas identificables como antijurídicas en el seno de la institución."

Claro está que también a estas relaciones de sujeción especial sigue siendo aplicable el art. 25.1, y, obviamente el principio de legalidad del art. 9.3 de la Constitución. Pero ello en este caso no puede tener el mismo alcance que en la potestad sancionadora general de la Administración ni mucho menos que respecto a las sanciones penales. Desde luego una sanción carente de toda base normativa legal devendría, incluso en estas relaciones, no sólo conculcadora del principio objetivo de legalidad, sino lesiva del derecho fundamental considerado, pero esa base normativa legal también existiría cuando la Ley, en este caso la Ley General Penitenciaria (arts. 42 y siguientes), se remita, en la especificación y gradación de las infracciones, al Reglamento. Ello permite reconocer la existencia de la necesaria cobertura de la potestad sancionadora en una norma con rango de Ley, y por ello debe rechazarse esta pretensión del recurrente. "73

La sentencia evita profundizar sobre el sentido específico de ese estatus de "sometimiento singular al poder público" que implica la relación de sujeción especial y su compatibilidad con las normas constitucionales. Tampoco se pronuncia sobre cuál sería la distinta naturaleza que tendría la potestad disciplinaria respecto de la sancionadora "general" de la administración, que determinaría cierta "pérdida" de la "fundamentación material" del principio de reserva de ley en favor de la potestad reglamentaria. Para el TC, el principio "objetivo" de legalidad se satisface si existe una base normativa legal que remite "en la especificación y gradación de las infracciones al Reglamento", aunque la ley le delegue expresamente la tipificación completa de las conductas constitutivas de faltas cuya infracción deba ser castigada con alguna de las sanciones previstas en la Ley General Penitenciaria. ${ }^{74}$

El recurrente de amparo adujo que, por la naturaleza particularmente grave de las sanciones impuestas, ellas eran de carácter "penal" y, en consecuencia, sólo podían ser irrogadas por un tribunal imparcial - y no por un órgano administrativo como lo era la Junta de Régimen y Administración de la prisión de Basauri- en razón del art. 6 del Convenio de Estrasburgo ${ }^{75}$

\footnotetext{
${ }^{73}$ La cursiva es nuestra.

74 El artículo 42.1 del Reglamento Penitenciario establece que, “[1]os internos no serán corregidos disciplinariamente sino en los casos establecidos en el Reglamento y con las sanciones expresamente previstas en esta Ley. Las infracciones disciplinarias se clasificarán en faltas muy graves, graves y leves."

${ }^{75} \mathrm{El}$ art. 6 de la Convención Europea de Derechos Humanos consagra diversos derechos vinculados al debido proceso o proceso equitativo, entre los cuales está el derecho a un tribunal independiente e imparcial, establecido por la ley, "que decidirá los litigios sobre sus derechos y obligaciones de carácter civil o sobre el fundamento de cualquier acusación en materia penal dirigida contra ella [toda persona].”
} 
HORVITZ, María Inés. "La insostenible situación de la ejecución de las penas privativas de libertad: ¿vigencia del Estado de derecho o estado de naturaleza?".

y del art. 24.2 de la Constitución. ${ }^{76}$ En apoyo de su razonamiento, el recurrente invocó un fallo del Tribunal Europeo de Derechos Humanos (TEDH) - Campbell y Fell contra Reino Unido $^{77}$ - que estableció que no bastaba la calificación de una medida como penal o disciplinaria por la legislación interna, sino que también debía otorgarse gran importancia a la naturaleza de la sanción, a que ésta excediera o no los «problemas de pura disciplina», y al grado de severidad de la sanción impuesta. Así, cuando ésta pudiera aparejar consecuencias especialmente graves, entonces «el objeto y el fin del Convenio exigen que la imposición de una medida de tal gravedad deba ser acompañada por las garantías del art. 6».

Junto con descartar que la sanción aplicada sea de orden penal, en el fundamento $4^{\circ}$ de su fallo, el TC justifica la inexigibilidad de independencia e imparcialidad del órgano que sanciona disciplinariamente en la doctrina de las relaciones de sujeción especial.

Del art. 6 del Convenio de Roma, no se deriva el que las sanciones impuestas al recurrente de amparo hubieran tenido que ser impuestas por un órgano independiente e imparcial, y, en consecuencia, no resulta aplicable aquí en toda su integridad, como el recurrente pretende, el art. 24.2 de la Constitución. Por todo ello encuentra plena aplicación al presente caso la doctrina sentada por la Sentencia 74/1985, de 18 de junio, según la cual el interno de un centro penitenciario está, respecto a la Administración Penitenciaria, en una relación de sujeción especial de la que deriva una potestad sancionatoria disciplinaria y que no tiene nada de anómalo ni de lesivo contra los derechos constitucionalizados en el art. 24.1 el que el órgano competente para imponer sanciones sea la Junta de Régimen y Administración, órgano no jurisdiccional, sino administrativo. «Es normal y aún necesario que cuando la Administración, en este caso la penitenciaría, actúa en ejercicio de su potestad disciplinaria, sean órganos administrativos los que la ejerzan, respecto a los cuales no es exigible esa neutralidad o imparcialidad en su composición que el recurrente reclama». ${ }^{78}$

En Chile, el arraigo y tradición de esta doctrina en la cultura jurídica ha tenido un peso gravitante para justificar el debilitamiento de los derechos y garantías de aquellas personas sometidas a vínculos especiales con el Estado ${ }^{79}$ a través de cierta "flexibilidad" en la exigencia del principio de legalidad, al tolerarse "una mayor apertura a la regulación reglamentaria respecto de las materias de reserva legal". ${ }^{80}$ Por otro lado, el TC ha rechazado la vigencia del principio de taxatividad en el ámbito de las infracciones y sanciones

\footnotetext{
${ }^{76}$ Que señala expresamente: “Asimismo, todos tienen derecho al Juez ordinario predeterminado por la ley, a la defensa y a la asistencia de letrado, a ser informados de la acusación formulada contra ellos, a un proceso público sin dilaciones indebidas y con todas las garantías, a utilizar los medios de prueba pertinentes para su defensa, a no declarar contra sí mismos, a no confesarse culpables y a la presunción de inocencia."

${ }^{77}$ Sentencia TEDH, de 28 de junio de 1984.

${ }^{78}$ La Ley General Penitenciaria prevé una composición meramente administrativa de los órganos que intervienen en la disciplina penitenciaria, y la judicialización de la ejecución de las penas a través de un sistema de control judicial (previo o posterior, según los casos), que resulta también aplicable a la protección de los derechos fundamentales de los detenidos. La cursiva es nuestra.

${ }^{79}$ Sobre el impacto de esta teoría en los códigos penales decimonónicos, y por consiguiente, en el chileno, cfr. GUZMAN, La pena, cit. nota ${ }^{\circ} 1$, pp. 187 ss.

${ }^{80}$ CORDERO, "El control", cit. nota n ${ }^{\circ} 35$, pp. 23ss.; GARRIDO, Mario, Derecho Penal. Parte General, T. I, Santiago: Ed. Jurídica de Chile, 2003, p. 155, quien, aunque no invoca expresamente esta doctrina, se refiere a las potestades disciplinarias y correctivas de la Administración respecto de las cuales "no rige el principio de legalidad" ni tampoco el "juicio previo" para la aplicación de las sanciones.
} 
disciplinarias, a pesar de que sí lo admite respecto del derecho administrativo sancionador. ${ }^{81}$ En el considerando vigésimo quinto del fallo Rol n 747 , de 31 de agosto de 2007, señaló;

Que no es obstáculo a lo razonado hasta aquí que esta Magistratura haya considerado, por mayoría, en sentencia reciente que el principio de legalidad debe aplicarse, con matices y por regla general a sanciones administrativas de multa, pues tal razonamiento se fundó en que las sanciones administrativas y las penas, aunque difieran en algunos aspectos, "forman parte de una misma actividad sancionadora del Estado y han de estar, en consecuencia, con matices, sujetas al mismo estatuto constitucional que las limita en defensa de la igual protección de la ley en el ejercicio de los derechos." Como se dijo en esos mismos fallos, la extensión del principio de legalidad penal al derecho administrativo sancionador se justifica "puesto que ambos son manifestaciones del ius puniendi propio del Estado", (considerando octavo de la sentencia de 8 de agosto de 2006, rol 479 y, en términos similares en la sentencia de misma fecha, rol 480). No cabe extender tales razones a la actividad disciplinaria del Poder Judicial, pues ésta no forma parte del ius puniendi del Estado, ni tiene por objeto la prevención general de sujetos indeterminados, sino la disciplina de quienes cumplen una determinada función pública y quedan por ello sujetos a especiales obligaciones cuyo cumplimiento resulta necesario para el buen funcionamiento de un órgano del Estado, todo ello en base a sus respectivos estatutos (la cursiva es nuestra).

En razonamientos previos, el TC se asiló en argumentos literales (como el empleo del vocablo "penal" por la Constitución) y en la disposición contenida en el artículo 20 del Código Penal, que dispone que no se reputan penas "las demás correcciones que los superiores impongan a sus subordinados y administrados en uso de su jurisdicción disciplinal o atribuciones gubernativas" [destacado de la sentencia], para justificar la exclusión del mandato constitucional de legalidad del art. $19 \mathrm{~N}^{\circ} 3$, de todo lo referido a los poderes disciplinarios de los superiores jerárquicos respecto de los subordinados mediante una diferenciación, entre correcciones administrativas y disciplinarias, que solo puede sostenerse en la doctrina de las relaciones de sujeción especial. ${ }^{82}$

\footnotetext{
${ }^{81}$ Así, la sentencia del TC de 26 de agosto de 1996 (Rol n 244) donde se lee que “(...) los principios inspiradores del orden penal contemplados en la Constitución Política de la República han de aplicarse, por regla general, al derecho administrativo sancionador, puesto que ambos son manifestaciones del ius puniendi propio del Estado" (considerando $9^{\circ}$ ), opinión que se mantiene en fallos posteriores (Roles $\mathrm{n}^{\circ} 437$, de 21 de abril de 2005; $\mathrm{n}^{\circ} 479$, de 8 de agosto de 2006; ${ }^{\circ}$ 480, de 27 de junio de 2006, entre otros). En esta misma línea se ha pronunciado la Corte Suprema (fallo de 11 de mayo de 2010, Rol n ${ }^{\circ} 4627-2008$ ) y la Contraloría General de la República, en Dictámenes n 14.571, de 22 de marzo de 2005, y n 28.226, de 22 de junio de 2007.

${ }^{82}$ En su razonamiento, el TC entiende que el ius puniendi solo puede predicarse de la potestad sancionadora de la Administración strictu sensu y solo en relaciones generales de sujeción. Esta distinción también es sostenida por la doctrina penal, cuando se afirma que las sanciones administrativas se clasifican en gubernativas y disciplinales, conceptualizando a las primeras como aquellas que la autoridad impone a cualquier ciudadano, mientras que las segundas sólo podrían irrogarse a quienes se encuentran vinculados con la organización administrativa por razones de subordinación, citándose al efecto las normas disciplinarias contenidas en el Código Orgánico de Tribunales, el Estatuto Administrativo y el Código de Justicia Militar. Se sostiene que, a diferencia de las sanciones gubernativas, las disciplinales son diferentes por completo de las penales pues carecerían de un auténtico bien jurídico y, por ello, "no precisan de una tipificación previa" (Cfr. CURY, Enrique, Derecho Penal, Parte General, $10^{a}$ ed., Santiago: Ediciones Universidad Católica de Chile, 2011, pp. 103 ss, p. 113ss y nota 389 con bibliografía comparada allí citada). CURY, sin embargo, rechaza esta postura
} 
HORVITZ, María Inés. "La insostenible situación de la ejecución de las penas privativas de libertad: ¿vigencia del Estado de derecho o estado de naturaleza?”.

Ya antes, en la sentencia Rol $\mathrm{N}^{\circ}$ 468, de 9 de noviembre de 2006, a propósito de la denuncia de inconstitucionalidad respecto del delito contemplado en el artículo 299 del Código de Justicia Militar ("incumplimiento de deberes militares") por remitirse a normas de rango inferior de carácter reglamentario la determinación de la conducta típica, el TC se refirió especialmente a dicha doctrina, en su considerando octavo:

Que, no obstante las opuestas interpretaciones presentes en el debate jurisdiccional expuesto, es indudable que una calificación nítida para el precepto bajo examen fluye de dos principales argumentos doctrinarios. Por una parte, se admite que la expresión "deje de cumplir sus deberes militares" es equivalente a describir el "núcleo central de la prohibición", para utilizar el concepto jurisprudencial constitucional español, tratándose de una conducta atribuible sólo a los militares, quienes, en tanto grupo de sujeción especial, conocerían sus deberes y, por lo tanto, las consecuencias de su no cumplimiento. Por otra parte, la remisión para describir la conducta punible se encuentra establecida en el propio cuerpo legal Código de Justicia Militar, al disponer el inciso primero de su artículo 431: "El Presidente de la República dictará en cada Institución los reglamentos correspondientes sobre los deberes militares, las faltas de disciplina, las reglas del servicio y demás necesarios para el régimen militar." Fundado en esta norma, se encuentra vigente el Reglamento de Disciplina para las Fuerzas Armadas, $\mathrm{N}^{\circ} 1.445$, de fecha 14 de diciembre de 1951, con modificaciones, cuyo Capítulo I, integrado por 28 artículos, se denomina "De los Deberes Militares". Con todo, esta remisión legal al Reglamento se cuestiona tanto por el rango de esta norma como por la debilidad de cognoscibilidad o de conocimiento claro acerca de la conducta punible, tomando en cuenta que no consta la publicación en el Diario Oficial del mencionado Decreto Supremo 1.445, seguida a su dictación (la cursiva es nuestra). ${ }^{83}$

El TC chileno no ha tenido aún la oportunidad de pronunciarse sobre la constitucionalidad del Reglamento Penitenciario; mientras crecientemente existen voces en la doctrina que apuntan en el sentido de su inconstitucionalidad. ${ }^{84}$ En nuestra opinión, el TC tiene

arguyendo que las sanciones disciplinarias, al igual que las administrativas, son parte de la potestad punitiva estatal y que la diferencia con las sanción es penales es solo de carácter cuantitativo (p. 114).

${ }^{83}$ En el considerando noveno, el TC expresa el fundamento del rechazo del requerimiento en los siguientes términos: "Que, sin perjuicio las observaciones expuestas y siguiendo el grueso de lo razonado precedentemente, puede afirmarse que la conducta descrita por el número 3 del artículo 299 del Código de Justicia Militar constituye la descripción suficiente del "núcleo central" de la conducta punible, pues dicha afirmación se sostiene en que los "deberes militares" no constituyen para los militares referencias indeterminadas o desconocidas, sino conceptos precisos con cuyo contenido los oficiales, cuyo es el caso del requirente, se familiarizan desde el inicio de su formación en las Escuelas Matrices de Oficiales de las Fuerzas Armadas, pues son parte de su malla curricular, y en torno a los que transcurre la totalidad de la vida castrense, además de vincularse directamente al carácter de "disciplinadas" que el artículo 101, inciso tercero, de la Constitución Política le otorga a las Fuerzas Armadas." En su voto particular, la Ministra Marisol Peña expresa "que lo anterior, confirma que el personal militar se encuentra sometido a una relación de "sujeción especial", como se afirma en el considerando $8^{\circ}$ de la sentencia, no aplicable o predicable exactamente de otros personales que integran la Administración del Estado" (considerando tercero).

${ }^{84}$ GUZMAN, "Consideraciones críticas", cit. nota n41, p. 275, cuando afirma que "[m]ás allá de tecnicismos formales y yendo al fondo jurídico del problema, si este decreto reglamentario no se compadece con la Constitución, por lo menos se acerca sensiblemente a su calificación de inconstitucional." CARNEVALI/ MALDONADO, "El tratamiento penitenciario", cit. nota n 45, pp. 407ss. 
competencia para efectuar un contraste de constitucionalidad con un decreto reglamentario, no obstante su conformidad con la ley. ${ }^{85}$ Esta tesis de la competencia amplia del TC ha sido sostenida de modo predominante a partir de $1997 .{ }^{86}$ Tratándose de la regulación de los derechos constitucionales de los reclusos, no afectados directamente por la pena, se impone el principio de reserva de ley y su tutela efectiva a través de un órgano jurisdiccional exclusivo, dadas las condiciones de encierro de los titulares de tales derechos y la necesidad de mecanismos expeditos de protección, especialmente frente a abusos de la propia administración penitenciaria. En efecto, los derechos constitucionales no pueden ser afectados en su esencia (art. $19 \mathrm{n}^{\circ} 26$ Const.) y es materia exclusiva de ley "[t]oda otra norma de carácter general y obligatoria que estatuya las bases esenciales de un ordenamiento jurídico" (art. 63 n 20 Const.). El art. 64 de la Constitución señala las restricciones de la potestad reglamentaria delegada del Presidente de la República, entre las cuales se halla la de extenderse a "materias comprendidas en las garantías constitucionales" (inciso $2^{\circ}$ ). Por consiguiente, si el constituyente vedó tal posibilidad respecto de la potestad reglamentaria delegada del legislador, con mayor razón ella debe encontrarse proscrita de la competencia reglamentaria común del Poder Ejecutivo, máxime cuando se trata de regular de forma general y obligatoria las bases esenciales del ordenamiento penitenciario y el ejercicio de los derechos constitucionales de los reclusos no afectados por la pena impuesta en la sentencia. ${ }^{87}$

Desde hace algunos años los órganos del sistema interamericano de protección de los derechos humanos han ido asentando la doctrina de que el Estado se encuentra en una posición de garante respecto de las personas privadas de libertad, transformando de este modo la lógica autoritaria de las relaciones de sujeción especial en una que constituye a la privación de libertad en fuente de deberes estatales de protección y aseguramiento en favor de los reclusos. ${ }^{88}$ El quebrantamiento de tales deberes acarrea la responsabilidad del Estado,

\footnotetext{
${ }^{85}$ En este caso, la norma legal atingente es la contenida en el art. 80 del Código Penal, la que dispone que: "Tampoco puede ser ejecutada pena alguna en otra forma que la prescrita por la ley, ni con otras circunstancias o accidentes que los expresados en su texto. Se observará también además de lo que dispone la ley, lo que se determine en los reglamentos especiales para el gobierno de los establecimientos en que deben cumplirse las penas, acerca de los castigos disciplinarios, de la naturaleza, tiempo y demás circunstancias de los trabajos, de las relaciones de los penados con otras personas, de los socorros que pueden recibir y del régimen alimenticio. En los reglamentos sólo podrán imponerse como castigos disciplinarios, el encierro en celda solitaria e incomunicación con personas extrañas al establecimiento penal por un tiempo que no exceda de un mes, $u$ otros de menor gravedad. La repetición de estas medidas deberá comunicarse antes de su aplicación al juez del lugar de reclusión, quien sólo podrá autorizarla por resolución fundada y adoptando las medidas para resguardar la seguridad e integridad, del detenido o preso."

${ }^{86}$ Cfr. CARMONA, Carlos, "Tres problemas de la potestad reglamentaria: legitimidad, intensidad y control", Revista de Derecho del Consejo de Defensa del Estado, año $1 \mathrm{n}^{\circ}$ 3, Santiago, (2001), pp. 29ss.
}

${ }^{87}$ En el mismo sentido, GUZMAN, “Consideraciones críticas”, cit. nota n 41, p. 275, nota 11. En sus palabras: "[a]unque el artículo 60 de la Constitución Política chilena [actual art. 63] no aborde la cuestión expressis verbis, permítaseme sugerir que si el artículo siguiente, el 61 [actual art. 64], excluye de las materias que pueden ser objeto de la potestad legiferante delegada del Ejecutivo "aquellas comprendidas en las garantías constitucionales" y, entonces, " a fortiori hay que entender precluído el paso, sobre semejantes materias, a la potestad reglamentaria común.”

${ }^{88}$ GÜNTHER, "Die Konstitutionalisierung“, cit. nota n54, pp. 304ss., quien denuncia el „largo camino“ de constitucionalización y reconocimiento del estatus jurídico al privado de libertad en Alemania, en el que habría tenido un rol relevante la comprensión de que los delitos no solo son cometidos -o al menos no únicamente- a través de una decisión libre y con consciencia de su antinormatividad por parte del autor, sino también por 
HORVITZ, María Inés. "La insostenible situación de la ejecución de las penas privativas de libertad: ¿vigencia del Estado de derecho o estado de naturaleza?”.

la mayoría de los cuales impone la actuación de las autoridades penitenciarias en orden a precaver los peligros inherentes al encierro, de modo que deba responderse también por omisión, dolosa o negligente. Así, en diversas ocasiones, la Corte Interamericana de Derechos Humanos ha señalado:

Que en virtud de la responsabilidad del Estado de adoptar medidas de seguridad para proteger a las personas que estén sujetas a su jurisdicción, la Corte estima que este deber es más evidente al tratarse de personas recluidas en un centro de detención estatal, caso en el cual el Estado es el garante de los derechos de las personas que se encuentran bajo su custodia. ${ }^{89}$

En el mismo sentido se ha pronunciado la Comisión Interamericana de Derechos Humanos, al adoptar los Principios y Buenas Prácticas sobre la Protección de las Personas Privadas de Libertad en las Américas, restringiendo notablemente las posibilidades de invocar circunstancias de exoneración de responsabilidad:

Toda persona privada de libertad que esté sujeta a la jurisdicción de cualquiera de los Estados Miembros de la Organización de los Estados Americanos será tratada humanamente, con irrestricto respeto a su dignidad inherente, a sus derechos y garantías fundamentales, y con estricto apego a los instrumentos internacionales sobre derechos humanos.

En particular, y tomando en cuenta la posición especial de garante de los Estados frente a las personas privadas de libertad, se les respetará y garantizará su vida e integridad personal, y se asegurarán condiciones mínimas que sean compatibles con su dignidad.

Se les protegerá contra todo tipo de amenazas y actos de tortura, ejecución, desaparición forzada, tratos o penas crueles, inhumanos o degradantes, violencia sexual, castigos corporales, castigos colectivos, intervención forzada o tratamiento coercitivo, métodos que tengan como finalidad anular la personalidad o disminuir la capacidad física o mental de la persona.

No se podrá invocar circunstancias, tales como, estados de guerra, estados de excepción, situaciones de emergencia, inestabilidad política interna, u otra emergencia nacional o internacional, para evadir el cumplimiento de las obligaciones de respeto y garantía de trato humano a todas las personas privadas de libertad ${ }^{90}$ (la cursiva es nuestra).

circunstancias de la estructura social y de la socialización, causas sociales en un sentido amplio, por lo que la sociedad, al ser corresponsable del delito, debe ayudar al delincuente a reinsertarse socialmente y a conducir una vida libre de delitos, doctrina sostenida por el TC alemán, en su sentencia de 5.6.1973 [caso Lebach] y luego plasmada en el parágrafo 2 de la Ley de Ejecución Penitenciaria.

${ }^{89}$ Cfr. Caso Gómez Paquiyauri, Medidas Provisionales. Resolución de la Corte Interamericana de Derechos Humanos de 7 de mayo de 2004, considerando decimotercero; caso de la Cárcel de Urso Branco, Medidas Provisionales. Resolución de la Corte Interamericana de Derechos Humanos de 22 de abril de 2004, considerando sexto; y caso de la Cárcel de Urso Branco, Medidas Provisionales. Resoluciones de la Corte Interamericana de Derechos Humanos de 29 de agosto de 2002, considerando sexto y de 7 de julio de 2004, considerando sexto.

${ }^{90}$ Principio I, Trato Humano. Resolución 1/08, OEA/Ser/L/V/II.131 doc. 26. Disponible en: www.oas.org/es/cidh/mandato/Basicos/PrincipiosPPL.asp [visitado el 20.12.2017]. 
A la lógica de la posición de garante parecieran responder, paradójicamente, las normas contenidas en los artículos $2^{\circ}$ y $4^{\circ}$, del Reglamento de Establecimientos Penitenciarios de 1998, las que se encontraban redactadas de la misma forma ya en el Reglamento anterior, Decreto $\mathrm{N}^{\circ}$ 1771, del Ministerio de Justicia, de 30 de diciembre de 1992. Su texto declara que:

Será principio rector de dicha actividad el antecedente que el interno se encuentra en una relación de derecho público con el Estado, de manera que fuera de los derechos perdidos o limitados por su detención, prisión preventiva o condena, su condición jurídica es idéntica a la de los ciudadanos libres (art. $2^{\circ}$ )

La actividad penitenciaria se desarrollará con las garantías y dentro de los límites establecidos por la Constitución Política de la República, los tratados internacionales ratificados por Chile y vigentes, las leyes y sus reglamentos y las sentencias judiciales.

Los funcionarios que quebranten estos límites incurrirán en responsabilidad, de acuerdo con la legislación vigente (art. $4^{\circ}$ ).

Empero, la realidad cotidiana de las cárceles chilenas contradice todo aquello que las fórmulas vacías del Reglamento tan ampulosamente declaran. ${ }^{91} \mathrm{La}$ mala fe de la Administración se revela en la equiparación declarativa de la condición jurídica de los reclusos a la de los ciudadanos libres, cuando se tiene a la vista la disposición constitucional que priva de la ciudadanía a los condenados a pena aflictiva. ${ }^{92}$

Lo que sí funciona, sin eufemismo alguno, es el gran poder disciplinario de la administración carcelaria -núcleo central del Reglamento- quien lo ejercita con discrecionalidad y sin fuertes controles externos, ${ }^{93}$ y en cuya virtud puede restringir los escasos derechos que se reconoce a los internos. ${ }^{94}$ Una importante manifestación de ese poder es el castigo de aislamiento en celda solitaria, que se utiliza sin apego a criterios de proporcionalidad, ${ }^{95}$ y que

91 ARRIAGADA, Isabel y ROCHOW, Diego "Privación de libertad en Chile: desgobierno carcelario y afectación de derechos de la población penal", en: Informe Anual de Derechos Humanos en Chile, Centro de Derechos Humanos, UDP, 2015, passim; HORVITZ, “Ejecución de las sentencias”, cit. nota n 43, pp. 585ss; MERA, Jorge, "Adecuación del derecho penal chileno al derecho internacional de los derechos humanos", en Medina, Cecilia y Mera, Jorge (editores) Sistema Jurídico y Derechos Humanos. Cuadernos de Análisis Jurídico Serie especial (1996), pp. 390ss.; CASTRO, Alvaro, CILLERO, Miguel y MERA, Jorge, Derechos fundamentales de los privados de libertad, Santiago: Ediciones UDP, 2010; SEPULVEDA, Eduardo, "El ordenamiento jurídico penitenciario", cit. nota $\mathrm{n}^{\circ} 45$, pp. 121ss.; GUZMAN DALBORA, José Luis, "Diagnósticos y perspectivas del binomio judicialización-jurisdiccionalización en el cumplimiento de las penas privativas de libertad”, Revista Brasileira de Ciências Criminais no 22 (1998), pp. 347ss.

92 Vid. infra. apartado 2.3.

${ }^{93}$ El art. 75 del Reglamento señala que “excepcionalmente”, los derechos de que gocen los internos podrán ser restringidos como consecuencia de alteraciones en el orden y la convivencia del establecimiento penitenciario o de actos de indisciplina o faltas, mediante las sanciones que en él se prevén. Resulta innecesario añadir que la concurrencia de los supuestos de hecho que autorizan la restricción de los derechos los califica la propia Gendarmería.

${ }^{94}$ En palabras de GUZMAN DALBORA, “(...) esto, en el fondo, equivale a decir que primero proclamamos ciertos principios generales de sentido garantizador, pero luego abrimos la puerta para violarlos de forma más o menos manifiesta mediante la concesión de poderes discrecionales $-\mathrm{y}$ ya se sabe cómo la discrecionalidad puede fácilmente degenerar en arbitrariedad- extensos a los funcionarios encargados de rendir cumplimiento a los principios que tanto nos interesan" ("Consideraciones críticas”, cit. nota n 41, p. 274).

${ }^{95}$ Estudios muestran su empleo habitual y de forma desproporcionada, muchas veces junto con otras sanciones disciplinarias como la suspensión de visitas, cfr. pp. 96ss. del Estudio de las condiciones carcelarias en los años 
HORVITZ, María Inés. "La insostenible situación de la ejecución de las penas privativas de libertad: ¿vigencia del Estado de derecho o estado de naturaleza?”.

puede durar hasta un mes, pudiendo ser repetida en la forma que señala el inciso final del art. 80 del Código Penal. ${ }^{96}$ El estricto régimen penitenciario y los efectos del encierro generan un constante clima de violencia que habitualmente deriva en el empleo abusivo de las facultades disciplinarias o, incluso, la comisión de delitos ${ }^{97}$ cuya investigación rara vez suele ser exitosa ${ }^{98}$ debido a la confluencia de numerosos factores: el temor a represalias de parte de los gendarmes, la complicidad o tolerancia de la propia autoridad penitenciaria, la ausencia de evidencia eficaz ${ }^{99}$ y la falta de confianza en la eficacia de las acciones judiciales. ${ }^{100}$

Si en el diseño legal la pena privativa de libertad consiste estrictamente en la afectación de la libertad ambulatoria del condenado, todas las otras vulneraciones de derechos constitucionales debieran estimarse inadmisibles por exceder los márgenes del merecimiento de pena. Sin embargo, la cárcel naturaliza estos excesos haciéndolos aparecer como "inherentes" al castigo, a pesar que constituyen una agravación injustificada de la pena. ${ }^{101}$ Lo anterior se refrenda con la reciente modificación al Código Penal a través de la Ley $\mathrm{N}^{\circ}$

2014-2015, elaborado por el INDH, en: http://bibliotecadigital.indh.cl/handle/123456789/1136 [visitado 25.07.2018]. Vid., para años anteriores, NASH, Claudio, MILOS, Catalina, AGUILÓ, PEDRO: "Personas privadas de libertad y medidas disciplinarias en Chile: análisis y propuestas desde una perspectiva de derechos humanos", Estudio del Centro de Derechos Humanos, Facultad de Derecho, U. de Chile, 2013, el que señala, entre otros interesantes datos, que según datos de Gendarmería, en 2011 el 87\% de las medidas disciplinarias aplicadas a nivel nacional consistió en castigo de aislamiento en celda solitaria (según el INDH, habría sido de 90,7\%), que de 4.644 reclusos/as que sufrieron este castigo en 2006 se pasó a 16.173 en 2011, aumentando en un $250 \%$ la cantidad de personas que lo sufrieron en ese periodo contra un $25 \%$ en que aumentó la población penitenciaria en ese mismo lapso. Hasta el lapso 2010-2012, entre el 79\% y el 90\% de las medidas disciplinarias que se imponían en las cárceles chilenas correspondían a aislamiento en celda solitaria. En: http://repositorio.uchile.cl/bitstream/handle/2250/122725/personas-privadas-de-

libertad.pdf?sequence=5\&isAllowed=y [visitado el 25.07.18].

${ }^{96}$ La "celda solitaria" fue abolida como pena accesoria recién en 1991, con la dictación de la Ley 19.047, en los inicios de la transición democrática; sin embargo, la misma ley la mantuvo como castigo disciplinario, pasando de ser irrogada por los tribunales de justicia bajo criterios legales, a ser aplicada discrecionalmente por Gendarmería.

${ }^{97}$ En febrero de 2015 se informaba por la prensa de la muerte de 558 presos en los últimos 4 años. A través de un requerimiento por transparencia, Gendarmería solo informó de 61 muertes "en riñas o agresiones" al interior de las cárceles durante 2014. Cfr. ARRIAGADA/ROCHOW, "Privación de libertad en Chile", cit. nota n 94, p. 181 y nota 63.

${ }^{98}$ En la Primera Mesa Ciudadana sobre el Sistema Penitenciario realizada en la Facultad de Derecho el 7 de enero de 2015, el Fiscal Regional de la zona Metropolitana Sur del Ministerio Público, Raúl Guzmán señaló algunos de los obstáculos, como el temor a las represalias, el carácter corporativo-militar, secretismo y autoprotección de Gendarmería (vid. ARRIAGADA/ROCHOW, "Privación de libertad en Chile", cit. nota n 94, p. 181.)

${ }^{99}$ Los internos suelen retractarse de sus denuncias por temor a represalias, los informes de lesiones suelen ser ambiguos y no concluyentes, y solo en contadas ocasiones la filtración de registros audiovisuales dados a conocer por los medios de comunicación, mostrando brutales golpizas a los reclusos, han reactivado las investigaciones y la atención de las autoridades (Cfr. ARRIAGADA/ROCHOW, "Privación de libertad en Chile", cit. nota $n^{\circ} 94$, p. 182.)

${ }^{100}$ CARNEVALI/MALDONADO, cit. nota ${ }^{\circ}$ 45, p. 407; STIPPEL, Jörg, Cárcel, derecho y política, cit. nota $\mathrm{n}^{\circ} 44$, pp. $187 \mathrm{ss}$.

${ }^{101} \mathrm{O}$ "epifenómeno inevitable" en palabras de GUZMAN DALBORA, quien cita a BUENO ARÚS como un autor que considera estos gravámenes como naturales a la esencia de la pena (La pena, cit., p. 187); MAÑALICH, Juan Pablo, "El derecho penitenciario entre la ciudadanía y los derechos humanos", Derecho y Humanidades, $\mathrm{N}^{\circ}$ 18, (2011), p. 169. 
20.968, de 22 de noviembre de 2016, que reforma los delitos de tortura. Ella introduce la misma disposición a los artículos 150 -A (inciso $5^{\circ}$ ), 150 -D (inciso $3^{\circ}$ ) y 255 (inciso $3^{\circ}$ ), todos del Código Penal, declarando atípicas y no constitutivos de los delitos de tortura, apremios ilegítimos $\mathrm{u}$ otros tratos crueles, inhumanos y degradantes, ni vejaciones injustas, respectivamente, "las molestias o penalidades que sean consecuencia únicamente de sanciones legales, o que sean inherentes o incidentales en éstas, ni las derivadas de un acto legítimo de autoridad". Una excepción similar se encuentra en la Declaración sobre Protección de todas las Personas contra la Tortura y otros Tratos o Penas Crueles, Inhumanos o Degradantes, adoptada por la Asamblea General en su Resolución 3452, de 9 de Diciembre de 1975. ${ }^{102}$ Sin embargo, en ella se hacen ciertas precisiones relevantes: "[n]o se considerarán torturas las penas o sufrimientos que sean consecuencia únicamente de la privación legítima de la libertad, o sean inherentes o incidentales a ésta, en la medida en que estén en consonancia con las Reglas Mínimas para el Tratamiento de los Reclusos."

Basta echar una mirada a su articulado para comprobar que el Estado de Chile no cumple con la mayoría de sus disposiciones. Pero no solo eso: tratándose de "las disciplinas y las sanciones", el artículo 31 prescribe que "[1] as penas corporales, encierro en celda oscura, así como toda sanción cruel, inhumana o degradante quedarán completamente prohibidas como sanciones disciplinarias." La decisión del legislador chileno de introducir una disposición despenalizadora de los excesos del sistema carcelario, burlando los estándares internacionales de tratamiento al recluso, hace evidente la (hasta ahora exitosa) estrategia de ocultamiento de una auténtica relación autoritaria de poder especial sobre los reclusos, cuya situación jurídica ha estado desde siempre entregada al arbitrio y autocontrol de la misma autoridad que infringe sus derechos y que ahora tendrá, probablemente, aún más espacio de impunidad.

Por otra parte, al legitimar la "administrativización" de la ejecución de las penas privativas de libertad, esta doctrina incidió en la demarcación que aún se hace doctrinariamente entre derecho penal y derecho penitenciario y, en el ámbito de la función de la pena, entre los momentos de irrogación y de ejecución de la pena, con la consiguiente des valorización del estatus jurídico de "lo carcelario", como veremos seguidamente.

\subsection{El hiato de los fines de la pena privativa de libertad en las fases de imposición y ejecución}

En efecto, la distinción teórica (e ideológica) entre la imposición jurisdiccional de la pena en la sentencia y su ejecución a cargo de los órganos de la administración penitenciaria, con específicos y disímiles fundamentos de legitimación, ha jugado un importante papel en la depreciación de la ejecución penal y en la consiguiente percepción de que ella no tiene mucho que ver con el derecho penal. ${ }^{103}$ Tal diferenciación "cualitativa" ha permitido levantar un

\footnotetext{
102 También por la Convención Interamericana para Prevenir y Sancionar la Tortura (art. 2), y la Convención contra la Tortura y otros Tratos o Penas crueles, inhumanos o degradantes, adoptada y abierta a la firma, ratificación y adhesión por la Asamblea General de las Naciones Unidas el 10 de diciembre de 1984 (art. $1^{\circ}$ ).

${ }^{103}$ En este sentido, KÜNSEMÜLLER,“La judicialización de la ejecución penal”, cit. nota n41, pp. 115 . También GUZMAN, La pena, cit. nota ${ }^{\circ} 1$, p. 188, quien afirma que el divorcio entre la imposición de la pena en la sentencia y su ejecución efectiva abrió "un portillo vacío de legalidad y presto a colmarse con los ribetes discrecionales de la Administración."
} 
HORVITZ, María Inés. "La insostenible situación de la ejecución de las penas privativas de libertad: ¿vigencia del Estado de derecho o estado de naturaleza?”.

muro de contención y de exclusión de los principios y garantías propios del derecho penal de un estado democrático de derecho en la fase de ejecución penitenciaria. Es más, la propia doctrina penal ha restado importancia a esta etapa de la pena, relegándola a la esfera puramente administrativa o, lo que es lo mismo, independizándola del derecho penal como si se tratara de una cuestión de orden regulativo inferior, de valor secundario. Un planteamiento que resume en pocas líneas el problema es el siguiente:

Con la determinación de la pena en la sentencia definitiva queda habitualmente terminada la tarea penal en el aspecto que a nuestra disciplina interesa. El cumplimiento mismo de la pena impuesta pasa a ser de ordinario reglamentado por el derecho administrativo en general y, tratándose de la pena privativa de libertad, al derecho penitenciario. ${ }^{104}$

Con algunas excepciones, ${ }^{105}$ la doctrina nacional apenas ha ahondado en el sentido y función de la pena durante su ejecución ni tampoco en una crítica severa hacia la falta de regulación legal y la desprotección jurídica que sufren los condenados a penas de encierro, limitándose a hacer una enumeración descriptiva de las escasas normas legales sobre la materia y de las contenidas en el Reglamento Penitenciario. ${ }^{106}$ Otros autores, aunque reconocen la importancia del derecho penitenciario y discrepan de su tratamiento separado del derecho penal, no profundizan mayormente sobre las consecuencias negativas que tal cesura conlleva para los derechos de los reclusos. Así, Cury niega que el derecho penitenciario pertenezca al derecho administrativo, señalando que se trata de "disposiciones que versan sobre la pena y, concretamente, sobre su realización efectiva mediante la ejecución", y que "ésta no es más que una parte del derecho penal, muy importante, por cierto, pero a la que no hay motivo alguno para segregar del conjunto". Este autor sugiere que la independización del derecho penitenciario del derecho penal lo ha convertido en una "especie de subsistema secundario

${ }^{104}$ ETCHEBERRY, Alfredo, Derecho Penal. Parte General, Tomo II, $3^{\text {a }}$ edición revisada y actualizada, Santiago: Ed. Jurídica de Chile, 1997, p.193.

${ }^{105}$ RIVACOBA, Manuel, "El problema de la substantividad y autonomía del Derecho penitenciario", en Revista de la Facultad de Derecho y Ciencias Sociales, año XIV, número 4, Universidad de la República, Montevideo, (1963), pp. 735ss.; GUZMAN, La pena, cit. nota $n^{\circ} 1$, pp. 163ss., del mismo, "Consideraciones críticas", cit., pp. 272ss.; MAÑALICH, "El derecho penitenciario", cit. nota n 104, pp. 163ss.; MERA, "Adecuación del derecho penal chileno", cit. nota ${ }^{\circ}$ 94, pp. 390ss.; KÜNSEMÜLLER (C) "La judicialización de la ejecución penal", cit. nota ${ }^{\circ} 41$, pp. 113ss., HORVITZ, María Inés, "Las medidas alternativas a la prisión. Su inserción en el sistema penitenciario chileno y presupuestos para su profundización en Chile", en BUSTOS, Juan, et.al., Acerca de la cárcel. Cuadernos de Análisis Jurídico ${ }^{\circ} 24$ (1993), pp. 51ss.

${ }^{106}$ Cfr. GARRIDO, Derecho Penal. Parte General, T. I, cit. nota n ${ }^{\circ} 82$, pp. 293ss., quien solo hace referencia a los fines de reinserción social de la ejecución penitenciaria señalados por el Reglamento; ETCHEBERRY, Derecho Penal, cit., nota ${ }^{\circ}$ 107, pp.193ss.; NOVOA, Eduardo, Curso de Derecho penal chileno. Parte General, T. II, $3^{\text {a }}$ ed., Santiago: Ed. Jurídica de Chile, 2005, pp. 308ss. Hace referencia a un "reciente" Decreto Supremo ( $\mathrm{N}^{\circ} 3140$, de 19.11.1965) en el que el Gobierno de la época sentaba las bases para una futura política penitenciaria, a la que debían orientarse las reformas legales y reglamentarias, y mejorar las deterioradas condiciones carcelarias, p. 310; LABATUT, Gustavo, Derecho Penal. Parte General, T.I, $4^{\mathrm{a}}$ ed., Santiago: Ed. Jurídica de Chile, 1963, p. 23 y pp. 509ss., CURY, Derecho Penal, cit. nota no 84, pp. 16-117, POLITOFF, Sergio, MATUS, Jean-Pierre, RAMIREZ, María Cecilia, Lecciones de Derecho Penal. Parte General, Santiago: Ed. Jurídica de Chile, 2004, p. 553, quienes únicamente advierten sobre la existencia de leyes penitenciarias y la institución del juez de ejecución de penas en el derecho comparado. 
de escasa relevancia", desvalorización que afecta el carácter preventivo general de la ejecución penitenciaria. ${ }^{107}$

La justificación teórica de la desvinculación de ambas fases de la práctica punitiva estatal ha venido de la mano del debate acerca de las funciones del derecho penal realizado por la doctrina comparada y asimilada parcialmente por la nacional. Un planteamiento que dio respaldo teórico y legitimó la separación de la ejecución de las penas con el momento de su irrogación fue el formulado por Roxin en la década de los 70, con notable influencia en los estudios dogmáticos de la época. ${ }^{108}$ Su teoría dialéctica de la unión pretendía superar de modo consistente las críticas dirigidas a las teorías pluralistas o mixtas dominantes en la época, que proponían soluciones eclécticas para justificar la pena estatal combinando criterios retributivos y preventivos. Este autor señala que, “(...) el Derecho penal se enfrenta al individuo de tres maneras: amenazando con, imponiendo y ejecutando penas; y que esas tres esferas de actividad estatal necesitan de justificación cada una por separado." ${ }^{109}$ En palabras de su discípulo Muñoz Conde, "(...) en el momento de la amenaza penal, es decir, cuando el legislador prohíbe una conducta amenazándola con una pena, es decisiva la idea de prevención general (...) pero si, a pesar de esta amenaza se llega a cometer el hecho prohibido, entonces a su autor debe aplicársele la pena prevista para ese hecho, predominando en la aplicación de la pena la idea retributiva. Finalmente, durante la ejecución de la pena impuesta, prevalece, sobre todo si se trata de una pena privativa de la libertad, la idea de prevención especial." 110

En la doctrina nacional, la discusión se mantiene en torno al fundamento y función de la imposición de la pena, ${ }^{111}$ mientras existe un mayor consenso acerca de la finalidad preventivo especial positiva de la ejecución penitenciaria. Más recientemente, y en la doctrina comparada, se ha discutido sobre el sentido de la ejecución del castigo para quienes centran la función de la pena en su dimensión comunicativa, cuya satisfacción se produciría con la sola irrogación de la pena en la sentencia. Tanto en la evolución de la concepción de Jakobs

107 "Esto, por supuesto, es en sumo grado inconveniente, porque la real eficacia de la pena se asegura, básicamente, en el momento de la ejecución, de manera que si aquél no se encuentra normado y organizado adecuadamente, el sistema fracasará, por excelentes que sean sus otras instituciones" (Derecho Penal. Parte General, cit., nota ${ }^{\circ}$ 84, p.116.) La cursiva es del texto.

${ }^{108}$ ROXIN, Claus, Problemas Básicos del Derecho Penal, Traducción de Diego Luzón Peña, Madrid: Ed. Reus, 1976.

${ }^{109}$ ROXIN, Problemas, cit. nota ${ }^{\circ} 111$, p. 20. Advierte, afirmando el carácter dialéctico de su teoría, que cada uno de los distintos estadios de realización del derecho penal "se estructuran unos sobre otros y que, por tanto, cada etapa siguiente ha de acoger en sí los principios de la precedente."

${ }^{110}$ MUÑOZ CONDE, Francisco, Introducción al Derecho Penal, Barcelona: Casa Editorial Bosch, 1975. p. 36.

${ }^{111}$ Aunque muchos autores no se pronuncien expresamente sobre el punto, la mayoría adhiere a alguna forma de prevención general, limitada por la culpabilidad; v.gr. CURY, Derecho penal, cit., nota $n^{\circ} 84$, pp. 76ss., quien cambia de opinión en su segunda edición declarándose "convencido (...) de que la retribución justa (...) no es una tarea para la cual sean competentes los tribunales del hombre"); GARRIDO, Derecho Penal (T.I), cit., nota ${ }^{\circ} 82$, p. 79, ETCHEBERRY, Alfredo, Derecho Penal. Parte General, Tomo I, $3^{\text {a }}$ edición revisada y actualizada, Santiago: Ed. Jurídica de Chile, 1998, p. 34. Para los menos, la pena solo se legitima como retribución de culpabilidad (v.gr. MAÑALICH, Juan Pablo, "La pena como retribución”, Estudios Públicos $\mathrm{N}^{\circ}$ 108 (2007), pp. 117-205). 
HORVITZ, María Inés. "La insostenible situación de la ejecución de las penas privativas de libertad: ¿vigencia del Estado de derecho o estado de naturaleza?".

sobre la prevención general positiva, ${ }^{112}$ como en el planteamiento que podría denominarse retributivo-funcional de la pena, ${ }^{113}$ se ha dicho que ésta tendría como única misión la de comunicar una reacción frente al delito para restablecer la norma como expectativa; en otras palabras, para reafirmar la vigencia de ésta. ${ }^{114}$ La prestación central del derecho penal es, entonces, contradecir la contradicción de la norma -la desautorización simbólica de su vigencia a través del hecho delictivo-, pues ella es determinante en la configuración de la identidad de la sociedad. Desde esta perspectiva, la pena se movería al margen del mundo empírico, lejos de las concepciones psicologicistas de la prevención general positiva, pues la pena no previene la comisión de delitos, sino que éstos dejen de concebirse como tales en el futuro. Más precisamente: ella misma es la consecución de esa finalidad, la constatación inmodificada de esa sociedad. ${ }^{115}$ Así, si la norma es depositaria de una expectativa social, entonces la pena, al reafirmar la vigencia de la norma, produce un efecto lógico (no empírico) de integración social.

Pero entonces, si la irrogación de la pena en la sentencia ya cumple sus fines comunicativos, ¿qué sentido tiene entonces la efectiva ejecución de la pena? Pues pareciera suficiente la declaración institucional de culpabilidad como acto de habla que expresa simbólica y contrafácticamente que la norma de comportamiento continúa siendo una pauta de conducta vinculante. En otras palabras,

“(...) si sólo importa" en la pena "su significado comunicativo de negación del delito y (de) afirmación de la norma, ¿por qué no habría de bastar la sola manifestación verbal de desacuerdo con el delito y (de) confirmación de la norma? ¿Por qué hay que añadir el mal empírico que implica la pena si este mal es en sí mismo irrelevante?’116

La idea de que la pena es pura comunicación es contraintuitiva: cuando se mete a alguien en la cárcel no se "habla" con el condenado, pues la comunicación concluyó antes, al emitirse

\footnotetext{
${ }^{112}$ Sobre esta evolución, vid. PEÑARANDA, Enrique, "Sobre la influencia del funcionalismo y la teoría de los sistemas en las actuales concepciones de la pena y del concepto de delito", DOXA n 23 (2000), pp.289-321.

${ }^{113}$ La plantea por primera vez el discípulo de Jakobs, Heiko Lesch, en su escrito de habilitación de Bonn de 1999 (Der Verbrechensbegriff. Grundlinien einer funktionalen Revision). Vid. LESCH, Heiko, La función de la pena, Trad. Sánchez-Vera, Javier, Madrid: Libros Dykinson, 1999. Lesch rechaza la denominación de «prevención general positiva», pues ella no resultaría adecuada para definir precisamente la función de la pena. En su opinión, ésta se agota en una retribución de la culpabilidad por el hecho, no absoluta, sino «funcional», en cuanto que dirigida a cancelar o saldar («ausgleichen»), la perturbación social (respecto de las expectativas de vigencia de la norma) provocada por el hecho (49ss.); JAKOBS, Günther, La pena estatal: significado y finalidad, Trad. y Estudio preliminar de Cancio, Manuel y Feijóo, Bernardo, Madrid: Thomson-Civitas, 2006, pp. 113.

${ }_{114}$ JAKOBS, Günther, Sociedad, norma y persona en una teoría de un derecho penal funcional, Traducción de Cancio, Manuel y Feijóo, Bernardo, Madrid: Civitas, 1996, pp. 17ss.

115 JAKOBS, Sociedad, cit. nota n ${ }^{\circ} 117$, pp. 18-19.

${ }^{116}$ MIR PUIG, Santiago, "Recensión al libro Sociedad, norma y persona en una teoría de un derecho penal funcional", Revista de Derecho Penal y Criminología, $2^{a}$ época, $N^{\circ} 2$ (1998), p. 4. El propio Jakobs se hace retóricamente la pregunta para desarrollar su nueva concepción teórica sobre la significación y finalidad de la pena estatal, cuando señala: “(...) permanece sin resolver la cuestión de por qué se elige el infligir dolor como símbolo, y no otra cosa. Pues si se tiene en cuenta que ya el fallo condenatorio constituye una contradicción del delito. ¿Por qué es necesario, además, un dolor producido por la pena?” (La pena estatal, cit. nota $\mathrm{n}^{\circ} 116, \mathrm{p}$. 135).
} 
el juicio de culpabilidad. ${ }^{117}$ En un notable giro hacia lo fáctico, ${ }^{118}$ Jakobs intenta resolver este problema afirmando que la pena no sólo es contradicción de la negación de la norma, representada por el delito, sino también tiene el fin (luego, ella deja de ser un fin en sí misma) de salvaguarda cognitiva de la vigencia de la norma, para producir una confianza real y no solo contrafáctica. ${ }^{119}$ En este sentido, entonces, la pena requiere facticidad, pues "en una sociedad en la que ninguna persona osa moverse por miedo a la delincuencia, el derecho a la libertad de movimientos no es real, se mire como se mire." ${ }^{20}$ De allí que para generar confianza en las víctimas potenciales sea necesario infligir dolor y producir miedo o convicción en los autores potenciales. Para Jakobs, "la prevención general negativa -junto con otros elementos, en particular, la producción de convicción- se halla contenida en la positiva, si bien simultáneamente es limitada por ésta de modo estricto a la reparación del daño culpablemente producido". ${ }^{121}$ Pero si la prevención general negativa no puede servir ni de fundamento ni de medida de la pena, ${ }^{122}$ ¿qué función cumple realmente en esta formulación mixta? Silva Sánchez, buscando una interpretación plausible de este pasaje, sugiere que "la situación de aseguramiento cognitivo de la norma, esto es, su mayor o menor estabilidad, cae de cuenta del autor que comete el hecho", de modo que "si lo comete en un estado de, por ejemplo, menor estabilidad de la norma, que hace precisa una mayor medida de pena, la mayor pena impuesta será, pues, adecuada a la culpabilidad". ${ }^{123}$ De esta forma, la objeción kantiana que se invoca para limitar los excesos de una pena fundada en la intimidación ${ }^{124}$ es transfigurada y busca ser sorteada - en un acto de mala prestidigitación-

${ }^{117}$ En este sentido, GÜNTHER, Klaus, "Straf(ab)gründe. Rechtsphilosophie in der Diskussion”, en KELLER, Bertram y SILLER, Peter (eds.) Rechtsphilosophische Kontroversen der Gegenwart, Nomos, Baden-Baden, 1999, p. 153.

${ }^{118}$ A partir de su trabajo programático Schuld und Prävention y hasta principios de los 90, JAKOBS sostuvo una teoría radicalmente preventivo-general, de carácter psicologicista, pasando luego a defender una teoría funcional de la retribución, en la que la idea de fin fue dejada fuera del discurso. Sin embargo, desde 2003, este autor abandona las perspectivas monistas para defender, como veremos en lo que sigue, una teoría de la pena mixta (cuyo trabajo paradigmático es Staatliche Strafe: Bedeutung und Zweck, citada en nota 79) que trata de conjugar o unificar las dos perspectivas anteriores y supone una recognitivización de su teoría de la pena, especialmente en relación a sus elementos preventivos; cfr. FEIJÓO, Bernardo, "Prevención general positiva. Una reflexión en torno a la teoría de la pena de Günther Jakobs“, en Anuario de Derecho Penal y Ciencias Penales, vol. LIX (2006), pp. 111-134.

${ }^{119}$ La irrogación de "dolor sirve para la salvaguarda cognitiva de la vigencia de la norma; este es el fin de la pena, como la contradicción de la negación de la vigencia por parte del delincuente es su significado."(JAKOBS, La pena estatal, cit. nota $\mathrm{n}^{\circ} 116$, p. 141).

${ }^{120} \mathrm{JAKOBS}$, La pena estatal, cit. nota $\mathrm{n}^{\circ} 116$, p. 139-140. Precisa que, "[p]ara hacer uso de su derecho, la persona no solo necesita seguridad normativa, es decir, la conciencia de que ejerce su derecho y de que, en caso de ser perturbada, esto se imputará al perturbador como falta suya y no a ella misma como temeridad; por el contrario, esta certeza normativa, si se pretende que verdaderamente dirija la conducta, debe contar con un apoyo cognitivo, dicho de otro modo, no debe ser demasiado elevada la posibilidad de que se convierta uno en víctima de un delito con ocasión del ejercicio de sus derechos."

${ }^{121}$ JAKOBS, La pena estatal, cit. nota $\mathrm{n}^{\circ} 116$, pp. 148-149.

122 JAKOBS, La pena estatal, cit. nota $\mathrm{n}^{\circ} 116$, pp. 156-157.

${ }^{123}$ SILVA, Jesús María, "Del Derecho abstracto al Derecho "real"”, InDret No4 (2006), p.5, en: http://www.indret.com/pdf/377_es.pdf [visitado el 20.07.2018].

124 "La ley penal es un imperativo categórico y, jay de aquel! que se arrastre por los caminos serpenteantes de la teoría de la felicidad para encontrar algún argumento que signifique, a través de una ventaja a la que él se comprometa, liberarlo o disminuir su pena sobre la base de la consigna farisea: "es mejor que un ser humano muera que echar a perder a todo el pueblo", pues cuando sucumbe la justicia entonces no tiene valor alguno que 
HORVITZ, María Inés. "La insostenible situación de la ejecución de las penas privativas de libertad: ¿vigencia del Estado de derecho o estado de naturaleza?”.

con el recurso a las necesidades del derecho "real", esto es, cargándolas a la cuenta del autor, lo que no solo transgrede el significado liberal y personalísimo del juicio de culpabilidad sino también conduce a los consabidos conflictos aporéticos de las teorías (mixtas) de la unión. ${ }^{125}$

La disociación entre la función expresiva de la pena de su facticidad como irrogación de un mal, esto es, la postulación de que junto con la declaración de culpabilidad de la sentencia de condena que impone la pena respectiva -que ya contaría como una prestación sancionatoriaha de añadirse la irrogación de un mal sensible, la efectiva ejecución de la pena, ${ }^{126}$ se justifica aquí en los fines de aseguramiento cognitivo de la vigencia de las normas cuyos beneficiarios son las potenciales víctimas de delitos. ${ }^{127}$ En esta formulación, la disociación entre, por una parte, la imposición de la pena y su ejecución, por la otra, cumple la función (ideológica) de consolidar a la primera como aquella que representa genuinamente la manifestación del ejercicio de la pretensión punitiva estatal, mientras la segunda, que comienza al "darse cumplimiento" a la sentencia definitiva, activaría una etapa por completo independiente, regida por principios, reglas y objetivos desvinculados de aquellas que legitiman el ius puniendi estatal. ${ }^{128}$

En esta fase cobra absoluta preponderancia la teoría de la prevención especial de la pena, la que ahora es formulada negativamente, como aseguramiento de una fuente de peligro:

La cuestión presenta mayor dificultad respecto de la prevención especial, el mejoramiento del autor mediante educación, su intimidación o su aseguramiento a través de medidas coactivas, desde el encierro, pasando por la castración de los llamados autores instintivos, hasta llegar a la pena de muerte. La pena privativa de libertad -generada con base en los esfuerzos educativos de orientación calvinista a finales del siglo XVI y que floreció desde la segunda mitad del siglo XVIII, entonces con base en la fe ilustrada en la educación- muy difícilmente hubiera comenzado su marcha triunfal, que se prolonga hasta el día de hoy, si no tuviera, junto con el fin preventivo "blando" "fidelidad a la norma mediante educación", también un fin duro: un preso ya no puede delinquir, más exactamente, no puede hacerlo fuera del centro penitenciario, más exactamente aún, allí ya no puede hacerlo de propia mano. Este efecto, como cualquier otro de índole preventivo-especial iconstituye un efecto secundario -muy deseado- del intento de asegurar la base cognitiva de la vigencia de la norma, o, por el contrario, es lícito perseguir tales efectos de modo autónomo, en cuanto fines de la pena a su vez legítimos? ${ }^{129}$

el ser humano viva en la tierra". Cfr. KANT, Immanuel, Metaphysische Anfangsgründe der Rechstlehre. Methaphysik der Sitten. Erster Teil, Hamburg: Felix Meiner Verlag, 1998, p. 155.

${ }^{125}$ En el mismo sentido, FEIJÓO, "Prevención general positiva", cit. nota n ${ }^{\circ} 121$, pp. 114ss.

${ }^{126}$ Cfr. MAÑALICH, "El derecho penitenciario", cit. nota n ${ }^{\circ}$ 104, p. 171-172. Para este autor, la función expresiva de carácter retributivo que cumple la sentencia de adjudicación de responsabilidad y la consiguiente imposición de la pena (retributivamente) merecida impide hacer la distinción. En este sentido, la ejecución penal solo puede ser vista como la materialización de un reproche de culpabilidad a través de la irrogación de un mal sensible; más ampliamente al respecto, vid. MAÑALICH, "La pena como retribución", cit., nota n 114, pp. 131ss.

${ }^{127}$ JAKOBS, La pena estatal, cit. nota ${ }^{\circ} 116$, pp. 135ss, esp. 139.

${ }^{128}$ MAÑALICH, "El derecho penitenciario", cit. nota n ${ }^{\circ}$ 104, p. 172.

${ }^{129}$ JAKOBS, La pena estatal, cit. nota $\mathrm{n}^{\circ} 116$, pp. 157-158. 
Jakobs distingue entre sujetos a los que "probablemente" se puede "ayudar a través de la educación a llevar en el futuro una vida sin pena, o de si se trata de proceder contra un peligroso autor por tendencia." ${ }^{30}$ Más preocupado de esta última hipótesis, se pronuncia críticamente sobre las limitaciones que el ordenamiento punitivo alemán opone a la posibilidad de que, por razones de aseguramiento, una pena pueda exceder la medida que determina la culpabilidad por el hecho, en tanto sólo admite, vicarialmente, la imposición de una medida de seguridad después de la pena y en determinados casos. ${ }^{131}$

Es más, este autor objeta que los intereses de salvaguarda no sean considerados ya en la determinación misma de los marcos penales. ${ }^{132} \mathrm{Su}$ postura, como es sabido, pasa a centrarse en quienes hacen del delito su modo de vida, "autores que obran a impulso de sus instintos, autores de tendencia, terroristas y otros en los que cabe identificar una tendencia consolidada hacia el delito, y parece un tanto ingenuo imponer (...) la pena sólo en virtud de la legalidad, sin pensar ya más en el aseguramiento." 133 En su opinión, resulta criticable que la Ley de Ejecución Penal ${ }^{134}$ consagre el fin de prevención especial a través de la educación "aún antes del aseguramiento frente a ulteriores hechos (...)", ${ }^{135}$ insistiendo en que quien no presta la garantía cognitiva de que se comportará como persona en Derecho, tampoco debe ser tratado como persona en Derecho, sino como enemigo. ${ }^{136}$ Este aseguramiento se dirige contra él en cuanto individuo peligroso; por lo tanto, en esa medida se le despersonaliza jurídicamente. ${ }^{137}$ La inocuización mediante aislamiento, cabe afirmar, se planteará ante signos más o menos estándares de peligrosidad o falta de garantía de fidelidad prospectiva a las normas, cuya calificación dependerá de cuánta seguridad cognitiva se requiera socialmente en un momento determinado. En este esquema, la imposición y la ejecución de la pena pierden toda connotación expresiva: se trata de acciones puramente instrumentales sobre el "penado", en las que no cabe su reconocimiento como sujeto racional y autónomo constituido en dignidad. ${ }^{138}$

En el ordenamiento jurídico nacional, la despersonalización jurídica- entendida como la privación de la ciudadanía [o de su ejercicio, en el caso de condenados a penas de prisión no aflictivas o de imputados en prisión preventiva], ${ }^{139}$ y del ejercicio de los derechos subjetivos públicos no afectados por la pena - ha sido prácticamente total cuando se trata de la pena de privación efectiva de la libertad. ${ }^{140}$ La prevención especial (positiva), entendida como actividad de "rehabilitación" que debiera desarrollar el Estado respecto del condenado a pena

\footnotetext{
${ }^{130} \mathrm{JAKOBS}$, La pena estatal, cit. nota $\mathrm{n}^{\circ} 116$, p. 158.

131 JAKOBS, La pena estatal, cit. nota $\mathrm{n}^{\circ} 116$, pp. 160-161.

132 JAKOBS, La pena estatal, cit. nota $\mathrm{n}^{\circ} 116$, pp. 161-162.

133 JAKOBS, La pena estatal, cit. nota ${ }^{\circ} 116$, p. 165.

${ }^{134}$ Art. 2 de la Ley (federal) de Ejecución penal vigente hasta 2006, pues en virtud de la reforma federal operada ese año, cada Estado alemán tiene la potestad de dictar leyes estatales sobre la materia. Ya en 2016, todos los estados alemanes tiene su propia ley penitenciaria.

135 JAKOBS, La pena estatal, cit. nota ${ }^{\circ} 116$, p. 159.

136 JAKOBS, La pena estatal, cit. nota $\mathrm{n}^{\circ} 116$, p. 167ss.

137 JAKOBS, La pena estatal, cit., nota $\mathrm{n}^{\circ} 116$, p. 172

${ }^{138}$ MAÑALICH, "La pena como retribución”, cit., nota ${ }^{\circ} 114$, pp. 170ss.

139 Solo recientemente, dos fallos de la Corte Suprema han ordenado al Servicio Electoral (Servel) que se adopten las medidas necesarias para que los recurrentes, personas privadas de libertad por condena a penas no aflictivas, puedan ejercer su derecho a voto (ambos de fecha 2 de febrero de 2017, Roles N $^{\circ} 87.743-2016$, y 87.748-2016).

${ }^{140}$ Vid. informe de Derechos Humanos y bibliografía citada en nota $n^{\circ} 46$.
} 
HORVITZ, María Inés. "La insostenible situación de la ejecución de las penas privativas de libertad: ¿vigencia del Estado de derecho o estado de naturaleza?”.

de cárcel ${ }^{141}$ hace tiempo ya que es un fraude de etiquetas, por el rotundo fracaso de siquiera impedir la desocialización que produce el encierro, y por la imposibilidad de educar para la libertad a una persona privada de libertad. ${ }^{142}$ Junto con ello, la práctica de estigmatización que significa la existencia de antecedentes penales y el paso por la cárcel dificulta enormemente la "reinserción" laboral, requisito indispensable para que un ex -interno pueda reconstruir sus redes de apoyo familiar y social, y más bien sienta las condiciones de la carrera criminal. ${ }^{143}$ Por ello, y a estas alturas, habría que preguntarse si puede seguir sosteniéndose con alguna seriedad el fin resocializador de la cárcel como fundamento legitimante de la ejecución de las penas privativas de libertad, como lo hace la legislación nacional y comparada, así como por los instrumentos internacionales de derechos humanos. ${ }^{144}$ En efecto, las condiciones inhumanas del encarcelamiento en las regiones menos desarrolladas, y los efectos criminógenos y desocializadores de su ejecución tras un cierto lapso han conducido, a partir de la segunda mitad del siglo XX, a que la pena privativa de libertad se siente en el banquillo de las sanciones consideradas inhumanas y degradantes, compartiendo el lugar con la pena de muerte que subsiste pertinazmente en algunos países considerados civilizados. ${ }^{145}$ En efecto, una pena de presidio cuya duración y condiciones de

${ }^{141}$ Cfr. Artículo $1^{\circ}$ del Reglamento Penitenciario.

${ }^{142} \mathrm{El}$ fracaso de la finalidad reeducativa es corroborado cotidianamente por las altas tasas de reincidencia: cfr. MORALES, Ana María, MUÑOZ, Nicolás, WELSCH, Gherman y FABREGA, Jorge, La reincidencia en el sistema penitenciario chileno, Fundación Paz Ciudadana y Universidad Adolfo Ibáñez, Santiago, 2012. En este sentido, CARNEVALI y MALDONADO, cit. nota n ${ }^{\circ} 45$, pp. 388ss; LARRAURI, Elena y JACOBS, James, "Reinserción laboral y antecedentes penales", Revista Electrónica de Ciencia Penal y Criminología $\mathrm{N}^{\circ} 13-09$, (2011), pp. 9:1-9:25.

${ }^{143}$ Para un estudio del efecto de rotulación y estigmatización que reciben solo algunos de los que ingresan al sistema penal, y de la criminalización secundaria, vid. el planteamiento del "etiquetamiento" (labeling approach), desarrollado por Howard BECKER, Edwin LEMERT, Frank TANNENBAUM, entre otros en: TAYLOR, Ian, WALTON, Paul y YOUNG, Jock, La nueva criminología. Contribución a una teoría social de la conducta desviada, $2^{\circ}$ reimpresión castellano, 1997, pp. 157ss..También, FOUCAULT, Vigilar y castigar, cit. nota $\mathrm{n}^{\circ} 1, \mathrm{p} .255$, quien advierte sobre la transformación que ocurre con el infractor una vez que ingresa a la cárcel: "Pero esto implica que el aparato penitenciario, con todo el programa tecnológico de que se acompaña, efectúa una curiosa sustitución: realmente recibe un condenado de manos de la justicia; pero aquello sobre lo que debe aplicarse no es naturalmente la infracción, ni aun exactamente el infractor, sino un objeto un poco diferente, y definido por unas variables que al menos al principio no estaban tomadas en cuenta por la sentencia, por no ser pertinentes sino para una tecnología correctiva. Este personaje distinto, por quien el aparato penitenciario sustituye al infractor condenado, es el delincuente."

${ }^{144}$ Cfr. a modo ejemplar, art. 25.2 Constitución española, art. 27 Constitución italiana; art. 5.6 de la Convención Americana de Derechos Humanos, entre otros. Cfr. GÜNTHER, "Die Konstitutionalisierung", cit. nota n ${ }^{\circ}$ 54, pp. 304ss., es tajante en afirmar que la resocialización dentro de un establecimiento penal es imposible en razón de sus inevitables consecuencias desocializadoras, por lo que, o se sigue insistiendo en alternativas a la prisión o se declara que la resocialización como fin de la ejecución penal es un fracaso, por irrealizable, y se opta por otros, como la retribución, la expiación, la defensa del ordenamiento jurídico o el aseguramiento. Continúa indicando que la tendencia generalizada es a la segunda opción por lo que denomina un „cambio de actitud“, en el que el autor del delito ya no es más percibido como una persona necesitada de auxilio y de asistencia social, sino alguien que, o se decidió libremente por el mal y por ello debe ser castigado, o causó sufrimiento a una víctima y, por lo tanto, debe repararla, o se trata de un individuo peligroso, cuyos motivos de actuación o situación de vida no se entienden o no se quiere entender y que debe ser aislado a fin que no siga cometiendo más daños. Dicho en pocas palabras: „,...) quien exige resocialización se preocupa nada más que del autor, pero ahora es finalmente el momento de pensar en la víctima“" (p. 306).

${ }^{145}$ Así, por ejemplo, Estados Unidos: en abril de 2017 se ejecutó respecto de 4 condenados a la pena capital en el Estado de Arkansas, mientras otros 4 esperan su turno, renovando la discusión acerca de su legitimidad. Cfr. https://www.washingtonpost.com/.../arkansas-readies-to-carry-out-. Vid. PALMER, Louis, The death penalty 
ejecución determinan que el sujeto desarrolle una "personalidad institucional", incongruente con el reconocimiento del destinatario del reproche como un agente moral, es una pena retributivamente injusta y retrospectivamente desproporcionada, una especie de "muerte de la personalidad." 146

Las distintas reformas legales que han introducido penas alternativas a la prisión, tanto en el derecho comparado como en Chile, no han logrado siquiera desplazarla a un segundo plano; más bien se añaden a ella, ampliando los medios y redes del control penal. ${ }^{147}$ La prisión, con sus tentáculos institucionales, no solo no se ha debilitado sino que goza de excelente salud y contemporáneamente se habla de la tercera "era del confinamiento"-prevista por Mathiesen hacia $1990-{ }^{148}$ marcada por el declive del welfarismo penal y de su paradigma resocializador y por el ascenso del modelo neoliberal del castigo, asentado en principios individualistas de racionalismo económico y moral, y su concepción de la cárcel, ya sin ambages, como un espacio de abierta neutralización y segregación. ${ }^{149}$

\subsection{La pérdida de la ciudadanía}

Entre los dispositivos de despersonalización del "delincuente", el más explícito y significativo está constituido por la disposición, de rango constitucional, ${ }^{150}$ que establece la

in the United States: a complete guide to federal and state laws, Mc Farland \& Company, Inc. Publishers, Jefferson, North Carolina, $2^{\text {nd }}$ ed., 2014; BAKKEN, Gordon (ed.): Invitation to an execution: a history of the death penalty in the United States, University of New Mexico Press, Albuquerque, 2010; WHITMAN, James, Harsch Justice. Criminal punishment and the widening divide between America and Europe, New York: Oxford University Press, 2003, pp. 3ss.

${ }^{146}$ MAÑALICH, "La pena como retribución", cit., nota n 114, p. 177.

${ }^{147}$ Cfr. COHEN, Stanley, Visiones de control social, PPU, Barcelona, 1988. Sobre las penas sustitutivas introducidas en Chile antes de la reforma de la Ley 20.603, de 2012, vid. HORVITZ , "Las medidas alternativas", cit. nota ${ }^{\circ} 108$, pp. 51-63. Una crítica de la regulación introducida por la Ley 20.603, cfr. PEÑA CAROCA, Ignacio, "Monitoreo telemático: análisis crítico desde la sociología del control y la economía del castigo", Revista de Estudios de la Justicia $\mathrm{N}^{\circ} 18$ (2013), pp. 161ss.

${ }^{148}$ Tras la explosión fundacional de los siglos XVII y XVIII y su consolidación en el siglo XIX, el siglo XX, especialmente sus últimas décadas marcan este giro. Cfr. MATHIESEN, Thomas, Prison on trial: a critical assessment, Sage, Londres, 1990, p. 14.

${ }^{149}$ En el contexto de países como Estados Unidos y otros que siguen políticas neoliberales de desregulación económica y disminución de las políticas sociales, la nueva etapa estaría marcada por la decadencia del Estado social fordista keynesiano y el surgimiento del Estado penal como técnica gubernamental de contención [punitiva] de la creciente marginalidad urbana producida por la contracción de los programas y ayudas sociales orientados a los sectores más pobres (p. ej., en EE.UU, con la abolición, en 1996, de la AFDC -Aid to Families with Dependent Children). Esta nueva cultura del control renuncia de modo creciente a la reinserción social en favor de la exclusión permanente de una clase de nuevos 'parias' relegada a los circuitos de las industrias carceleras y de la reincidencia periódica. Vid. WACQUANT, Loïc, Castigar a los pobres. El gobierno neoliberal de la inseguridad ciudadana, Barcelona: Gedisa, 2010; PIVEN, Frances, CLOWARD, Richard, Regulating the poor: the functions of public welfare, Vintage, New York, 1993. En la misma orientación, pero negando preponderancia al neolberalismo entre las causas del fenómeno, GARLAND, David, La cultura del control: crimen y orden social, Barcelona: Gedisa, 2005.

${ }^{150}$ Art. $17 \mathrm{~N}^{\circ} \mathrm{s} 2$ y 3 Constitución chilena. MARSHALL destaca la importancia simbólica que se le confiere a esta regla al constitucionalizarla -lo que no sería frecuente en el derecho comparado- y, desde el punto de vista práctico, las dificultades procedimentales para su reforma y las limitaciones del legislador para corregirla. Además, denuncia la falta de desarrollo legal y administrativo del procedimiento que permita a los condenados a pena aflictiva recuperar su ciudadanía una vez cumplida la pena. Cfr. MARSHALL, Pablo, "La persecución 
HORVITZ, María Inés. "La insostenible situación de la ejecución de las penas privativas de libertad: ¿vigencia del Estado de derecho o estado de naturaleza?”.

pérdida de la ciudadanía en los casos de condena por delitos que merezcan pena aflictiva. ${ }^{151 / 152}$

Como señaláramos en un principio, esta disposición tiene su origen en la Constitución chilena de 1822, que a su vez la copió literalmente de la Constitución de Cádiz de 1812, y de allí se mantuvo, con algunos matices de diferencia (excepto en la Constitución de 1823 que sólo establecía la suspensión, y no la pérdida de la ciudadanía), en las Cartas de 1828, 1833 y 1925. En todo este periodo y hasta 1972, el concepto de ciudadanía estaba limitado al grupo de personas habilitada para participa en la vida política y electoral ${ }^{153} \mathrm{y}$, en tal sentido, carecía de la plena dimensión democrática. Y ello, como veremos, tiene importancia para la justificación (retrospectiva) de la imposición de la pena, en tanto reproche institucionalizado por la falta de seguimiento leal de una norma de comportamiento a la que se encuentra vinculada como destinatario solo en cuanto participante (potencial) en el procedimiento de su establecimiento.

Como ha apuntado Mañalich, "[b]ajo una justificación democrática de la pena, un sujeto condenado por un hecho punible debe conservar su condición de ciudadano, pues la legitimidad (de las consecuencias) del reproche que se expresa en la pena presupone su reconocimiento como miembro de la comunidad política". ${ }^{154}$ En efecto, en una sociedad constituida democráticamente, secularizada y pluralista, las normas ya no descansan en fundamentos sustancialistas a priori, sino en el entendimiento comunicativo para la coordinación justa de intereses en el proceso de integración social. ${ }^{155}$ Un concepto fundamental aquí es el de libertad o autonomía comunicativa, que consiste en la "posibilidad recíprocamente presupuesta en la acción comunicativa, de tomar postura frente a una

penal como exclusión política", en MUÑOZ, Fernando (ed.) Derecho, igualdad e inclusión, Santiago: LOM editores, 2013, pp.69ss.

${ }^{151}$ De conformidad con el art. 37 Código Penal, "[p]ara los efectos legales se reputan aflictivas todas las penas de crímenes y, respecto de las de simples delitos, las de presidio, reclusión, confinamiento, extrañamiento y relegación menores en sus grados máximos." De facto, tampoco pueden ejercer sus derechos políticos los condenados a penas menores que cumplen el encierro ni tampoco los que están sometidos a medidas cautelares personales, pues no se encuentran habilitados los mecanismos institucionales para el efecto (vid. infra ap. 3).

${ }^{152}$ La idea de criminal como enemigo social, como un individuo que ha roto el pacto social tiene origen ilustrado y tal quiebre debía dejar al culpable al margen de la condición de ciudadano durante el cumplimiento de la condena; cfr. FOUCAULT, Michel, La verdad y las formas jurídicas, Gedisa, Barcelona, 1996 pp. 89ss.

${ }^{153}$ En efecto, estuvo fuertemente restringido durante el siglo XIX y gran parte del siglo XX, primero, por la precariedad de la institucionalidad democrática abiertamente intervenida por el poder ejecutivo y un sistema político autoritario que se expresó en la Constitución de 1833. Un hito importante fue la reforma electoral de 1874 que amplió el derecho de sufragio; y la Ley de Comuna Autónoma aprobada tras la Revolución de 1891 en que se consagró la independencia de los municipios del gobierno central. El poder político siguió concentrado en una reducida elite hasta la irrupción de movimientos sociales y la conformación de partidos políticos de izquierda en la década del 20 y 30, y su victoria electoral en 1938 con el Frente Amplio. En 1935 se permitió el voto femenino en las elecciones municipales y en 1949, en las presidenciales. La introducción de la cédula única electoral en 1958 incentivó la participación electoral y frenó los abusos. En 1969 se aprobó el voto de ciegos y en 1972 el de los analfabetos. En 2012 se reformó el sistema de sufragio universal, introduciendo la inscripción automática y el voto voluntario.

${ }^{154}$ MAÑALICH, Juan Pablo, "Pena y ciudadanía", en Revista de Estudios de la Justicia Nº 6 (2005), pp. 6383.; del mismo, "La pena como retribución", cit., nota n 114 , pp. 168ss.

155 KINDHÄUSER, Urs, "La fidelidad al derecho como categoría de la culpabilidad", en KINDHAUSER, Urs y MAÑALICH, Juan Pablo, Pena y culpabilidad en el estado democrático de derecho, Lima: Ara Editores, 2009, pp. 98ss. 
elocución o manifestación de un prójimo y frente a las pretensiones de validez entabladas con esa manifestación, las cuales se enderezan a un reconocimiento intersubjetivo." 156 Lo distintivo del procedimiento democrático consiste en hacer depender el carácter vinculante del derecho a los discursos públicos y a los procedimientos de decisión, en los cuales todos los ciudadanos tienen derecho a participar. Cuando se trata del entendimiento acerca de las normas, cada participante desempeña un doble papel: por un lado, es autor de la norma, y en tal medida goza de autonomía pública; por el otro, es destinatario de la norma, la que le confiere un espacio de juego para la acción y, por consiguiente, para el desempeño de su autonomía privada. ${ }^{157}$ Autonomía pública (que constituye al sujeto como ciudadano) y autonomía privada (que lo constituye en persona de derecho- Rechtsperson) se entrecruzan en la constitución de la autonomía comunicativa que condiciona la posibilidad de vincular al sujeto a la norma (de comportamiento) como su destinatario, en tanto la norma puede ser reconducida al propio sujeto como interviniente (potencial) en el procedimiento de su establecimiento. ${ }^{158}$

Y es importante destacar que las normas jurídicas, establecidas conforme a los procedimientos democráticos de un determinado ordenamiento jurídico, también valen respecto de aquellas personas que gozan de autonomía pública pero que no hacen ejercicio de su derecho subjetivo de participación política, pues "no está[n] obligada[s] a hacer uso fáctico de la capacidad atribuida de posicionamiento crítico como participante[s] en discursos públicos." ${ }^{159}$ Como ciudadano, la persona deliberativa tiene derecho a oponerse a la norma, plantear su modificación o supresión; pero ella no puede invocar este mismo derecho en su rol de persona de derecho o destinatario de la norma: en este caso se impone su seguimiento en razón de su deber de "lealtad comunicativa". La persona de derecho, como destinatario de la norma de comportamiento, dispone de un ámbito de libertad instrumental determinado por el mandato de neutralidad; pero el rechazo del acuerdo que expresa la norma debe justificarse en el marco de los procedimientos institucionales establecidos para su revisión. De allí que la lealtad comunicativa, como correlato de libertad comunicativa atribuida a la persona deliberativa, consiste, precisamente, en no arrogarse unilateralmente ese cambio de roles. ${ }^{160}$

Con el quebrantamiento de la norma, el autor niega el entendimiento sobre el cual descansa la norma y así también la autonomía comunicativa de los intervinientes, con independencia de si el autor considera, por las razones que fuere, que la norma es

\footnotetext{
${ }^{156}$ HABERMAS, Jürgen, Facticidad y validez. Sobre el derecho y el estado democrático de derecho en términos de la teoría del discurso, (Traducción Manuel Jiménez Redondo), Madrid; Trotta, 1998, p. 185, quien cita a GÜNTHER, Klaus, "Die Freiheit der Stellungnahme als politisches Grundrechts", en KOLLER, Peter et.al (eds.) "Theoretische Grundlagen der Rechtspolitik", Archiv für Rechts-und Sozialphilosophie, vol. 54 (1992), pp. 58ss; KINDHAUSER, "La fidelidad al derecho", cit. nota n 156, p. 100.

${ }^{157}$ GÜNTHER, Klaus, Schuld und kommunikative Freiheit, Frankfurt a.M.: Vittorio Klostermann, 2005, pp. $245 \mathrm{ss}$.

${ }^{158}$ MAÑALICH, "Pena y ciudadanía", cit. nota n ${ }^{\circ}$ 157, p. 66. Esta noción también se corresponde con la de "persona deliberativa" elaborado por GÜNTHER, esto es aquella a quien se reconoce libertad comunicativa, entendida como la capacidad de posicionamiento crítico en tanto se apoye en razones. Según el autor alemán, las razones se definen por el hecho de que ellas "hacen una diferencia en el mundo, en tanto pueden motivar a una persona a la revisión y modificación de sus manifestaciones y acciones” (vid. Schuld, cit. nota $\mathrm{n}^{\circ} 160$, pp. 245ss.).

${ }^{159}$ GÜNTHER, Schuld, cit. nota n ${ }^{\circ} 160$, p. 250.

${ }^{160}$ GÜNTHER, Schuld, cit. nota n 160, p. 253; MAÑALICH, "Pena y ciudadanía”, cit. nota n 157, p. 68.
} 
HORVITZ, María Inés. "La insostenible situación de la ejecución de las penas privativas de libertad: ¿vigencia del Estado de derecho o estado de naturaleza?”.

irracional o injusta. No es su racionalidad, sino la lealtad comunicativa frente a la autonomía de los demás, lo que vincula al autor con la norma. Es evidente que una lealtad comunicativa así circunscrita, en la cual descansa el efecto vinculante, con carácter legitimador, de las normas democráticas, cuenta como fidelidad al derecho. En un Estado democrático de derecho, la culpabilidad es, formulado aún de manera sumamente genérica, un actuar que expresa una falta de fidelidad al derecho, esto es, un déficit de aquella lealtad comunicativa que hace en general posible el entendimiento que asume forma jurídica. Un concepto de culpabilidad así entendido implica sin duda también un vis á tergo que morigera la culpabilidad: una socialización del autor en que no se manifestó suficientemente el actuar orientado al entendimiento. ${ }^{161}$

Por consiguiente, si la imputación a la culpabilidad a quien infringió la norma de comportamiento se entiende como un reproche por una falta de lealtad comunicativa, en el sentido (reactivo) de reprobación por una conducta incorrecta, tal juicio no es compatible con una actitud objetivante respecto del sujeto a quien se reprocha la decisión por esa conducta incorrecta. La reprobación, como el resentimiento, es una actitud reactiva, forma parte de nuestra experiencia cotidiana, y presupone la consideración del destinatario del reproche como un participante en la comunicación. ${ }^{162}$ Pero este reproche sólo es legítimo bajo la condición de que la persona haya tenido la posibilidad de tomar parte, como ciudadano, en el procedimiento democrático en el cual se establece y se revisa la validez de la norma.

La incompatibilidad entre el reproche que se funda en una actitud reactiva y la adopción de una actitud objetivante radica en que esto último implica ver al otro como un "objeto de táctica social", como un individuo que ha de ser sujeto a tratamiento, respecto del cual hay que adoptar, eventualmente medidas preventivas. La adopción de una actitud reactiva, y aun la irrogación de un mal como consecuencia, en cambio, supone que al sujeto se lo sigue considerando miembro de la comunidad, puesto que "tales actitudes de desaprobación e indignación son precisamente los correlatos de la demanda moral cuando se siente que la demanda ha sido ignorada". 163

En suma, el rechazo de la perspectiva instrumental significa afirmar que el individuo "no puede ser subordinado como medio para la obtención de fines heterónomos- como, por ejemplo, a la voluntad de terceros, a una orientación objetivada del bien común o a la utilidad del sistema." 164 Para autores como Jakobs, sin embargo, la comisión de un delito no solo implica la idea de retribución como contradicción comunicativa del hecho delictivo, sino también la idea preventiva de fin (prevención general para ciudadanos, prevención especial negativa para enemigos), esto es, el deber de irrogar un mal a quien es declarado culpable por su comisión para el aseguramiento cognitivo de la vigencia de la norma quebrantada. Pero además, con la ejecución de la pena se busca limitar "el alcance comunicacional del delincuente" a través de la declaración simbólica de su incompetencia, esto es, "se le ejecuta o se le impide el uso de sus facultades, encerrándolo, se le priva del medio principal de intercambio para obtener libertad, del dinero, entre otras cosas, en resumidas cuentas: al autor se le suspende total o parcialmente como destinatario y emisor en la comunicación." 165 Más

${ }^{161}$ KINDHÄUSER, "La fidelidad al derecho", cit. nota n ${ }^{\circ} 158$, pp. 107-108.

${ }^{162}$ MAÑALICH, "Pena y ciudadanía", cit. nota n 157 , p. 69.

${ }^{163}$ MAÑALICH, "Pena y ciudadanía", cit. nota n 157 , p. 70.

${ }^{164}$ KINDHÄUSER, "La fidelidad al derecho", cit. nota n ${ }^{\circ} 158$, p.99.

${ }^{165}$ JAKOBS, La pena estatal, cit. nota $\mathrm{n}^{\circ}$ 116, p. 133. 
adelante, sin embargo, el efecto pareciera ser aún más radical, pues no bastaría la mera suspensión en la comunicación:

“(...) después de un delito, no basta con denominar delincuente al autor -esto, por sí solo, es únicamente una corroboración conceptual-, sino que también ha de ser tratado como delincuente, para avanzar hacia la realización del concepto y mantener la fuerza de orientación, la vigencia, del Derecho. Del mismo modo que después de una expectativa cognitiva la orientación no se restablece sin más porque el sujeto defraudado corrobore lo errado de su cálculo, sino que, al contrario, éste ha de corregir tal cálculo, tampoco bastará después de la defraudación de una expectativa normativa con identificar al autor como fuente de la defraudación; debe ser tratado realmente como autor, es decir, debe ser eliminado en cuanto destinatario en la comunicación de modo más o menos completo y por tiempo más o menos largo."166

Como resulta evidente, esta concepción es precisamente la que se halla detrás de la regulación constitucional nacional. En palabras de Mañalich, “[s]i la Constitución chilena niega la calidad de ciudadano al sujeto a quien se impone una pena privativa o restrictiva de libertad de duración superior a tres años, la Constitución hace inviable la construcción de un derecho penal del ciudadano. Y la alternativa a un derecho penal del ciudadano es, inevitablemente, un derecho penal del enemigo." 167

La pérdida de la ciudadanía fue el corolario que sentó el Iluminismo por la a ruptura del pacto social que significaba la comisión del delito, una idea que tenía "metida en la sangre como un residuo de situaciones pasadas" 168 y que, sin embargo, pervive hasta hoy de modo incongruente con las bases de la práctica punitiva en un Estado democrático de derecho.

\section{Actuación de la jurisdicción con competencia en materia penitenciaria}

En un Estado democrático de derecho con principios republicanos, la administración penitenciaria no debería estar sujeta al autocontrol cuando se trata de la afectación de derechos constitucionales, siendo aún insuficiente el control jurisdiccional que ejercen los tribunales de justicia a través de los recursos de amparo y protección, o las atribuciones que el CPP confiere a los jueces de garantía.

Hasta la implementación de la reforma procesal penal, e incluso durante sus primeros años, la situación era de absoluta desprotección jurisdiccional: en el sistema procesal penal inquisitivo los jueces del crimen carecían de competencia en la esfera de la ejecución penal y las visitas carcelarias solo tuvieron $-\mathrm{y}$ siguen teniendo- alguna incidencia en la denuncia de las condiciones carcelarias, pero nunca han sido usadas como parte de un procedimiento de tutela para la corrección o sanción de abusos en contra de los internos. ${ }^{169}$ Con relación a acciones constitucionales ante los tribunales superiores de justicia, un estudio de la Universidad Diego Portales examinó más de 9.000 recursos de protección presentados ante la Corte de Apelaciones de Santiago entre 1990 y 1998, como también resoluciones dictadas

\footnotetext{
166 JAKOBS, La pena estatal, cit. nota ${ }^{\circ} 116$, p. 143.

${ }^{167}$ MAÑALICH, "Pena y ciudadanía", cit. nota $n^{\circ} 157$, p. 76.

${ }^{168}$ FREUDENTHAL, citado por GUZMAN, La pena, cit. nota ${ }^{\circ} 1$, p. 188.

${ }^{169}$ Cfr. por ejemplo, el Informe Anual de Derechos Humanos 2006, de la Universidad Diego Portales, pp. 158ss.
} 
HORVITZ, María Inés. "La insostenible situación de la ejecución de las penas privativas de libertad: ¿vigencia del Estado de derecho o estado de naturaleza?”.

por la Corte Suprema entre 1998 y 2003, entre los cuales solo 98 estaban referidos a recursos de reclusos en contra de Gendarmería. ${ }^{170}$ La mayoría de esos 98 recursos invocó como derecho constitucional afectado la salud; ${ }^{171}$ y solo el $7,1 \%$ fue acogido. ${ }^{172}$

Otro estudio sobre acciones constitucionales, pero referido únicamente a los interpuestos por reclusos, fue llevado a cabo por un organismo alemán de cooperación y desarrollo (GTZ), entre enero de 2003 y enero de 2004, con el apoyo y patrocinio del Ministerio de Justicia. ${ }^{173}$ La investigación abarcó 459 recursos de amparo y de protección presentados en las jurisdicciones de Santiago y San Miguel durante los años 2000, 2001 y 2002, interpuestos por condenados a penas privativas de libertad. El trabajo da cuenta, en general, que del total de los recursos de amparo y protección analizados, el 60,8\% (279) fue declarado admisible; el 33,6\% (154) fue declarado inadmisible y el 5,7\% (26) no fue sometido a tramitación. Considerando los recursos declarados inadmisibles y los que fueron acogidos a trámite pero rechazados en el fondo, la cifra se eleva a un 94,1\%, y tan sólo un 5,9 \% obtuvo un resultado favorable al recurrente. El mayor porcentaje de recursos se presenta por maltratos sufridos en la prisión (17,2\%), seguido por sanciones disciplinarias no justificadas (16,4\%). Los demás casos abarcan conflictos por decisiones sobre traslados, por problemas de salud, cumplimiento de la libertad condicional, entre otros reclamos.

No obstante, en tiempos recientes se advierten signos auspiciosos de cambio en algunos fallos dictados por los tribunales superiores de justicia y el control que ejercen los tribunales de garantía a instancias de los defensores penitenciarios, quienes invocan diversas disposiciones del Código Procesal Penal (en adelante, CPP), como la "cautela de garantías" (art. 10), el amparo del art. 95, o la audiencia innominada del art. $466 .{ }^{174}$

La necesidad de un control jurisdiccional especial y efectivo también viene impuesto por el sistema interamericano de derechos humanos, $\mathrm{y}$ reconocido por los órganos correspondientes $^{175}$. Así, los Principios y Buenas Prácticas sobre la Protección de las Personas Privadas de Libertad en las Américas, contiene uno sobre control judicial y ejecución de la pena, el principio VI:

El control de legalidad de los actos de la administración pública que afecten o pudieren afectar derechos, garantías o beneficios reconocidos en favor de las personas privadas de libertad, así como el control judicial de las condiciones de privación de libertad y la supervisión de la ejecución o cumplimiento de las penas, deberá ser periódico y estar a cargo de jueces y tribunales competentes, independientes e imparciales.

\footnotetext{
${ }^{170}$ GOMEZ, Gastón, Derechos fundamentales y recurso de protección, Santiago: Ediciones Universidad Diego Portales, Facultad de Derecho, 2005.

${ }^{171}$ GOMEZ, Derechos fundamentales, cit. nota n ${ }^{\circ} 172$, tabla 43, p. 534.

${ }^{172}$ GOMEZ, Derechos fundamentales, cit. nota ${ }^{\circ} 172$, p. 530. El autor destaca que ninguna resolución se refiere a los derechos constitucionales del recluso, y para el rechazo de los recursos se argumenta que tales materias son de atribución exclusiva de Gendarmería de Chile.

${ }^{173}$ Sobre los resultados del estudio cfr. STIPPEL, Cárcel, cit. nota n ${ }^{\circ} 44$, pp.187ss.

${ }^{174}$ ARRIAGADA/ROCHOW, "Privación de libertad en Chile", cit. nota n 94, p. 168.

${ }_{175}$ Resolución 1/08, de la Comisión Interamericana de Derechos Humanos. OEA/Ser/L/V/II.131 doc. 26. Disponible en: www.oas.org/es/cidh/mandato/Basicos/PrincipiosPPL.asp
} 
Los Estados Miembros de la Organización de los Estados Americanos deberán garantizar los medios necesarios para el establecimiento y la eficacia de las instancias judiciales de control y de ejecución de las penas, y dispondrán de los recursos necesarios para su adecuado funcionamiento.

Como se ha destacado previamente, en Chile no existe la figura del juez de ejecución de penas, con atribuciones exclusivas en la materia. La figura más cercana es el juez de garantía, el que de conformidad con el artículo 14, letra f), del Código Orgánico de Tribunales, tiene la obligación de "hacer ejecutar las condenas criminales y las medidas de seguridad, y resolver las solicitudes y reclamos relativos a dicha ejecución, de conformidad a la ley procesal penal." Pero el CPP es muy parco al respecto, limitándose a señalar quiénes son los intervinientes autorizados para intervenir en esta fase de la práctica punitiva estatal, ${ }^{176}$ y escuetamente las disposiciones legales sobre ejecución de las penas privativas de libertad. ${ }^{177}$ No obstante, y a pesar de las restricciones legales e ideológicas que hemos descrito en este trabajo, algunas señales indican que los tribunales están siendo más receptivos y otorgan mayor atención a esta problemática. No cabe duda que a tal fin ha contribuido la Defensoría Penal Pública ${ }^{178}$ y organismos de protección de los derechos humanos, ${ }^{179}$ cuya activa intervención en la etapa de ejecución de las penas ha dado lugar, en el último tiempo, a cierta jurisprudencia que hace pensar en una creciente sensibilidad de los tribunales sobre los abusos y excesos de la actividad penitenciaria. En ellos ha tenido especial importancia el reconocimiento explícito de que Gendarmería, en representación del Estado de Chile, tiene una posición de garante frente a la persona privada de libertad. ${ }^{180}$ Así, los tribunales superiores de justicia han acogido, en los últimos años, diversos recursos de amparo por

\footnotetext{
176 Art. 466 CPP. Intervinientes: "Durante la ejecución de la pena o de la medida de seguridad, sólo podrán intervenir ante el competente juez de garantía el ministerio público, el imputado, su defensor y el delegado a cargo de la pena sustitutiva de prestación de servicios en beneficio de la comunidad, de libertad vigilada o de libertad vigilada intensiva, según corresponda. El condenado o el curador, en su caso, podrán ejercer durante la ejecución de la pena o medida de seguridad todos los derechos y facultades que la normativa penal y penitenciaria le otorgare."

${ }^{177}$ La única norma relevante es la contenida en el art. 468 CPP, que se limita a la actividad de dar "orden de ingreso" al establecimiento penitenciario que corresponda, cuando se trate de la imposición de una pena privativa de libertad.

${ }^{178}$ A través de su Unidad de Defensa Penitenciaria, la que desde algún tiempo publica periódicamente la jurisprudencia favorable en la materia.

${ }^{179}$ Principalmente, el Instituto de Derechos Humanos.

180 “Que, Gendarmería en representación del Estado, es garante de la seguridad individual de toda persona que se encuentra bajo su custodia, lo que se encuentran acorde con el texto del artículo 21 de la Constitución Política de la República y las disposiciones del Decreto Supremo N ${ }^{\circ}$ 518, Reglamento de Establecimientos Penitenciarios, especialmente lo dispuesto en sus artículos $1^{\circ}$ y $6^{\circ}$ en relación al artículo 15 de la Ley $2589 . "$ (por ejemplo, considerando $4^{\circ}$ Roles 156 y 158-2013 Corte Concepción); “Que, en cualquiera de las versiones, no puede soslayarse que, al interior del centro penitenciario, el amparado (...) sufrió una herida cortopunzante en el cuello y exhibe también varios hematomas en su cuerpo, respecto de las cuales Gendarmería no puede deslindar responsabilidad, pues en todos los casos tiene el deber de cuidado de quienes se encuentren internos en los centros de cumplimiento penitenciario. La Excma. Corte Suprema en sentencia de 28 de diciembre de 2012, Rol 2618-2012, ha establecido que, conforme a la normativa que regula las funciones del servicio de Gendarmería de Chile, éste es responsable no sólo de la vigilancia de los internos sino que, además, debe velar por la integridad física de las personas que se encuentran privadas de libertad." (considerando $4^{\circ}$ causa Rol $^{\circ}$ 14-2014 (Corte Concepción)).
} 
HORVITZ, María Inés. "La insostenible situación de la ejecución de las penas privativas de libertad: ¿vigencia del Estado de derecho o estado de naturaleza?”.

maltrato físico y lesiones causadas a internos por personal de Gendarmería, ${ }^{181}$ también por abuso en la imposición de medidas disciplinarias; ${ }^{182}$ recursos de protección por denegación de derecho de visitas $;{ }^{183}$ recursos de amparo por revocación arbitraria de Gendarmería de permisos de salida u otros beneficios penitenciarios; ${ }^{184}$ recursos de amparo por traslados arbitrarios; ${ }^{185}$ entre otros casos.

Especial notoriedad ha alcanzado un reciente fallo de la Corte Suprema, recaído en recurso de amparo presentado por Lorenza Cayuhán Llebul, mujer mapuche, embarazada, quien fue reiteradamente "engrilletada" durante el trabajo de parto. La Corte Suprema consideró que existió una "interseccionalidad en la discriminación", observando

“(...) una confluencia de factores entrecruzados de discriminación que se potencian e impactan negativamente en la amparada, pues ésta recibió un trato injusto, denigrante y vejatorio, dada su condición de mujer, gestante y parturienta, privada de libertad y perteneciente a la etnia mapuche, lo que en forma innecesaria puso en riesgo su salud y su vida, así como la de su hijo, todo ello, en contravención de la normativa internacional vigente en la materia. Estas reglas han advertido que la convergencia de múltiples formas de discriminación aumenta el riesgo de que algunas mujeres sean víctimas de discriminación compuesta, por lo cual la entidad recurrida, Gendarmería de Chile, afectó la seguridad personal de la amparada durante la privación de libertad que sufría con motivo de las penas impuestas y su dignidad como persona, en contravención a la Constitución Política y las leyes, debiendo en consecuencia ser acogida la acción de amparo interpuesta en su favor, adoptándose las medidas necesarias para restablecer el imperio del derecho." 186

El caso Cayuhán ha sentado un hito en la materia y se espera que genere una jurisprudencia favorable en el respeto de los derechos de la persona privada de libertad. A ello se añade la actuación de algunos tribunales instando a los poderes públicos a proveer los mecanismos para el ejercicio de los derechos políticos. ${ }^{187}$ La propia Corte Suprema a través de dos fallos muy recientes -ambos de 2 de febrero de 2017-, recaídos en recursos de protección

${ }^{181}$ Rol N ${ }^{\circ} 15.266-2013$ (Corte Suprema) / Roles 156 y 158-2013 Corte Concepción; 3809-2014 (Corte Suprema) / 14-2014 (Corte Concepción); Rol № 29-2014 (Corte Pto. Montt); Rol 3809-2014 (Corte Suprema) / 14-2014 (Corte Concepción); Rol No 7823-2015, de 22 de junio 2015 (Corte Suprema) / Rol No 97-2015 (Corte Concepción); Rol N`711-2015 (Corte Suprema) / 123-2014 (Corte Arica); Rol N¹24-2016 (Corte Concepción); Rol N¹27-2016 (Corte de Valparaíso).

${ }^{182}$ Rol N ${ }^{\circ} 343-2014$ (Corte Suprema); Rol N 6450-2015 (Corte Suprema); Rol N 26-2015 (Corte La Serena); Rol N 17-2015 (Corte La Serena); Rol N 31538-2014 (Corte Suprema); Rol N 9515-2016 (Corte Concepción, recurso de protección); Rol N${ }^{\circ} 164-2015$ (Corte Concepción).

${ }^{183}$ Rol N${ }^{\circ} 33141-2014$, de 15 de julio de 2015.

${ }^{184}$ Rol N$^{\circ}$ 1506-2014 (Corte Suprema) /Rol No 94-2013 (Corte de Rancagua); Rol No 56-2014 (Corte La Serena); Rol N 145-2013 (Corte de Copiapó); Rol N 56-2014 (Corte de Puerto Montt); Rol N686-2016 (Corte de Talca).

${ }^{185} \mathrm{Rol} \mathrm{N}^{\circ}$ 16.575-2014 (Corte Suprema); Rol No 5932-2013 (Corte Suprema); 12207-2015 (Corte Suprema) / 99-2015 (Corte Arica); Rol No 26.492-2014 (Corte Suprema).

${ }^{186} \mathrm{Rol} \mathrm{N} \mathrm{N}^{\circ} 92.795-2016$, de $1^{\circ}$ de diciembre de 2016 , considerando $16^{\circ}$.

${ }^{187} \mathrm{Cfr}$. la polémica ocurrida por la resolución de un juez de garantía ordenando al Servicio Electoral adoptar las medidas necesarias para que imputados pudieran votar, en el siguiente sitio web: http://www.latercera.com/noticia/juez-ordena-a-servel-habilitar-mesas-para-que-imputados-voten-en-lascarceles/ [ visitado el 20.12.2017]. 
presentados por el Instituto Nacional de Derechos Humanos en favor de personas en prisión preventiva, señaló que

\begin{abstract}
“(...) se debe tener presente que la Constitución Política, en su artículo $1^{\circ}$, asegura el derecho de las personas a participar con igualdad de oportunidades en la vida nacional, siendo el derecho a voto una de las herramientas de participación ciudadana más relevante y afín con la democracia, motivo por el cual se deben implementar las medidas necesarias para resguardar el ejercicio de ese derecho a quienes aun cuando están privados de libertad, no tienen suspendido su derecho a voto".
\end{abstract}

El máximo tribunal acogió los recursos y ordenó al Servicio Electoral adoptar las medidas necesarias que posibiliten el ejercicio del derecho a sufragio de los recurrentes privados de libertad, cuyo derecho constitucional no se encuentra suspendido, y a Gendarmería de Chile, adoptar igualmente las medidas administrativas y de coordinación interinstitucional que garanticen el derecho a voto de los mismas, "medidas que deberán ejecutarse con la antelación debida que permita a las personas antes referidas ejercer efectivamente su derecho a voto".

\title{
4. Conclusiones
}

Hace largo tiempo que el Estado de Chile se encuentra en mora en la satisfacción de los estándares internacionales de protección de los derechos de las personas condenadas a penas privativas de libertad, infracción especialmente grave dada su posición de garante. En este trabajo se indaga en los dispositivos teóricos e institucionales que han permitido instalar, afianzar y perpetuar la exclusión del estado de derecho en las cárceles nacionales, manifestada notoriamente en la ausencia de legalidad de la ejecución de las penas privativas de libertad y en la (aún) débil jurisdiccionalidad de los actos abusivos de la administración penitenciaria.

Las condiciones carcelarias expresivas de hard treatment y el menoscabado estatus jurídico de los reclusos ponen en evidencia el carácter excesivo de la pena privativa de libertad, en la medida que tales males se añaden al (único) que resultaría retributivamente merecido, tornando cruel y desproporcionada la reacción punitiva. En efecto, la pragmática de la pena justa y merecida presupone la exclusión de todas aquellas formas de castigo que degradan o despersonalizan a quienes sufren su imposición, esto es, que atacan la idea misma de dignidad humana y de agente moral, racional y autónomo.

Si el fundamento del carácter vinculante de las normas en un estado democrático de derecho está en el desempeño de los roles de autor y destinatario de las mismas, la privación de la ciudadanía a los condenados a penas aflictivas (y la obstaculización fáctica del ejercicio de derechos políticos a los demás) plantea déficits de legitimidad democrática en el ejercicio de la práctica punitiva estatal. Y si junto con ello no existen mecanismos institucionales efectivos de checks and balances que garanticen el ejercicio de los derechos constitucionales no afectados por la pena -pese al retórico y débil reconocimiento reglamentario-, no cabe dirigir un genuino reproche de culpabilidad al condenado: la privación de libertad pasa a constituirse en una reacción inmoral, ilegítima e injustificada. 
HORVITZ, María Inés. "La insostenible situación de la ejecución de las penas privativas de libertad: ¿vigencia del Estado de derecho o estado de naturaleza?”.

En esta perspectiva, el condenado a una pena de encierro deja de ser visto como co-agente racional y moral, para convertirse en mero objeto de táctica social. En los planteamientos preventivos de la pena, cualquiera sea su fundamentación, prevalece una actitud objetivante de instrumentalización del condenado, ya sea para disuadir a otros de la comisión futura de delitos o ya para el aseguramiento (cognitivo) de fuentes de peligro. Cuando se trata de la neutralización del peligroso, la privación de libertad como encierro y aislamiento social es solamente congruente con los fundamentos de las medidas de seguridad. De allí que hablar de pena en estos casos constituye un fraude de etiquetas, pues aquello que se denomina "pena privativa de libertad" no es más que una medida de seguridad dirigida a la inocuización de quienes son considerados un "peligro para la sociedad". En este ámbito no gobierna el estado de derecho, sino que reina el estado de naturaleza. 
Polít. crim. Vol. 13, N²6 (Diciembre 2018) Art. 7, pp. 904-951.

[http://www.politicacriminal.cl/Vol_13/n_26/Vol13N26A7.pdf]

\section{Bibliografía}

ABELEIN, Manfred, "Rechtsstaat und besonderes Gewaltverhältnis", Rechtsschrift für Politik, vol. $14 \mathrm{~N}^{\circ} 3$ (1967), pp. 313-332.

ARRIAGADA, Isabel y ROCHOW, Diego, "Privación de libertad en Chile: desgobierno carcelario y afectación de derechos de la población penal", en Informe Anual de Derechos Humanos en Chile, Santiago: Centro de DD.HH, UDP, 2015, pp. 161207.

BAKKEN, Gordon Morris (ed.), Invitation to an execution: a history of the death penalty in the United States, Albuquerque: University of New Mexico Press, 2010.

BECCARIA, Cesare, Tratado de los delitos y de las penas, Madrid: Universidad Carlos III, 2015.

CANO MATA, Antonio, "Derecho administrativo penitenciario: protección del recluso", Revista de Administración Pública no 76 (1975), pp. 31-61.

CARMONA, Carlos, "Tres problemas de la potestad reglamentaria: legitimidad, intensidad y control", Revista de Derecho del Consejo de Defensa del Estado, Año $1 \mathrm{~N}^{\circ} 3$ (2001), Santiago, pp. 29-43.

CARNEVALI, Raúl y MALDONADO, Francisco, "El tratamiento penitenciario en Chile. Especial atención a problemas de constitucionalidad", en Revista Ius et Praxis, año 19, $\mathrm{N}^{\circ} 2$ (2013), Universidad de Talca, pp. 385-418.

CASTRO, Álvaro; CILLERO, Miguel y MERA, Jorge, Derechos fundamentales de los privados de libertad, Santiago: Ediciones UDP, 2010.

COHEN, Stanley, Visiones de control social, Trad. Elena Larrauri, Barcelona: Ediciones PPU, 1988.

CORDERO, Eduardo, "El control de jurisdiccionalidad de la administración penitenciaria", Doctrina Procesal Penal (Informes en Derecho), Santiago: Defensoría Penal Pública, 2009.

CURY, Enrique, Derecho Penal, Parte General, 10ª ed., Santiago: Ediciones Universidad Católica de Chile, 2011.

DAVID, Valeska, "Entrevista a Mónica Maldonado. Las condiciones carcelarias en Chile", en Anuario de Derechos Humanos, № 6 (2010), pp. 211-222.

ETCHEBERRY, Alfredo, Derecho Penal. Parte General (Tomos I y II), $3^{\text {a }}$ edición revisada y actualizada, Santiago: Ed. Jurídica de Chile, 1997.

FEEST, Johannes, LESTING, Wolfgang y SELLING, Peter, Totale Institution und Rechtsschutz- Eine Untersuchung zum Rechtsschutz im Strafvollzug, Opladen: Westdeutscher Verlag, 1997.

FEIJÓO, Benito: "Prevención general positiva. Una reflexión en torno a la teoría de la pena de Günther Jakobs“, Anuario de Derecho Penal y Ciencias Penales (ADPCP) vol. LIX (2006), pp. 111-134.

FLEINER, Fritz, Instituciones de Derecho Administrativo, Barcelona: Editorial Labor, 1933. FOUCAULT, Michel, La verdad y las formas jurídicas, Barcelona: Gedisa, 1996.

FOUCAULT, Michel, Vigilar y castigar, Trad. Garzón, Aurelio, Buenos Aires: Siglo XXI, 2002.

FOUCAULT, Michel, La sociedad punitiva. Curso en el College de France 1972-1973, Trad. Pons, Horacio, México: Fondo de Cultura Económica, 2016. 
HORVITZ, María Inés. "La insostenible situación de la ejecución de las penas privativas de libertad: ¿vigencia del Estado de derecho o estado de naturaleza?".

FREUNDENTHAL, Berthold, "La posición jurídico-pública del preso", Trad. Guzmán Dalbora, José Luis, Revista Peruana de Ciencias Penales, Nº 13 (2003), pp. 351362.

GALLEGO ANABITARTE, Alfredo, "Las relaciones especiales de sujeción y el principio de legalidad de la Administración”, Revista de Administración Pública (1961), 34, pp. 11-51.

GARCÍA MCO, Ricardo, Las relaciones de especial sujeción en la Constitución española, Madrid: Tecnos, 1992

GARLAND, David, "Sociological perspectives on punishment", en Tonry, Michael (ed.), Crime and Justice: A Review of Research, vol. 14 (1991), University of Chicago Press, pp. 115-165.

GARLAND, David, The Culture of Control: Crime and Social Order in Contemporary Society, Chicago: University of Chicago Press, 2001.

GARRIDO, Mario, Derecho Penal. Parte General,Tomo I, Santiago: Ed. Jurídica de Chile, 2003.

GASCON y MARÍN, José, Tratado de Derecho Administrativo, $10^{\mathrm{a}}$ ed., Madrid: Bernego, 1950.

GOFFMAN, Erving, Internados: ensayo sobre la situación social de los enfermos mentales, Buenos Aires: Amorrortu Editores, 1972.

GÓMEZ, Gastón, Derechos fundamentales y recurso de protección, Santiago: Ediciones Universidad Diego Portales, 2005

GUAITA MARTORELL, Aurelio, Derecho Administrativo especial, Zaragoza: Librería General, 1960.

GÜNTHER, Klaus, "Die Freiheit der Stellungnahme als politisches Grundrechts", en KOLLER, Peter et.al (eds.) "Theoretische Grundlagen der Rechtspolitik", Archiv für Rechts-und Sozialphilosophie, vol. 54 (1992), pp. 58-73.

GÜNTHER, Klaus, "Straf(ab)gründe. Rechtsphilosophie in der Diskussion”, KELLER, Bertram y SILLER, Peter (eds.) Rechtsphilosophische Kontroversen der Gegenwart, Baden-Baden: Nomos, 1999, pp. 147-155.

GÜNTHER, Klaus, "Die Konstitutionalisierung des Strafvollzuges durch das Bundesverfassungsgericht. Ein Beispiel für die Fragilität der Verfassungsdynamik", Kritische Vierteljahresschrift für Gesetzgebung und Rechtswissenschaft, vol. 83, Nr. 3/4 (2000), pp. 298-312.

GÜNTHER, Klaus, Schuld und kommunikative Freiheit, Frankfurt a.M.; Vittorio Klostermann, 2005.

GUZMÁN DÁLBORA, José Luis, "Consideraciones críticas sobre el reglamento penitenciario chileno", en BAIGÚN, David, ZAFFARONI, Eugenio, GARCÍAPABLOS, Antonio y PIERANGELI, José (editores) De las penas. Homenaje al Profesor Isidoro de Benedetti, Buenos Aires: De Palma, 1997, pp. 271-280.

GUZMÁN DÁLBORA, José Luis "Diagnósticos y perspectivas del binomio judicializaciónjurisdiccionalización en el cumplimiento de las penas privativas de libertad", Revista Brasileira de Ciências Criminais, $\mathrm{n}^{\circ} 22$ (1998), pp. 347-359.

GUZMÁN DÁLBORA, José Luis, "Justicia penal y principio de humanidad", Gaceta Jurídica ${ }^{\circ} 298$ (2005), pp. 36- 45

GUZMÁN DÁLBORA, José Luis, La pena y la extinción de la responsabilidad penal, Santiago: LegalPublishing, 2008. 
Polít. crim. Vol. 13, N²6 (Diciembre 2018) Art. 7, pp. 904-951.

[http://www.politicacriminal.cl/Vol_13/n_26/Vol13N26A7.pdf]

HABERMAS, Jürgen, Facticidad y validez. Sobre el derecho y el estado democrático de derecho en términos de la teoría del discurso, Traducción Jiménez Redondo, Manuel, Madrid: Trotta, 1998.

HERNÁNDEZ, Héctor, "Comentario al artículo 80”, en Couso, Javier y Hernández, Héctor (Directores), Código Penal Comentado. Libro Primero (arts. $1^{\circ}$ a 105) Doctrina y Jurisprudencia, Santiago: Abeledo Perrot/UDP, 2011.

HORVITZ, María Inés, "Las medidas alternativas a la prisión. Su inserción en el sistema penitenciario chileno y presupuesto para su profundización en Chile" en BUSTOS, Juan et.al., Acerca de la cárcel, Cuadernos de Análisis Jurídico $\mathrm{N}^{\circ} 24$ (1993), Escuela de Derecho Universidad Diego Portales, pp. 51-57.

HORVITZ, María Inés, "Ejecución de las sentencias condenatorias y de las medidas de seguridad", en HORVITZ, María Inés y LÓPEZ, Julián Derecho procesal penal, Tomo II, Santiago: Ed. Jurídica de Chile, pp. 585-600, 2004.

HOWARD, John, State of the prison in England and Wales, with preliminary observations and an account of some foreign prisons, New York: Cambridge University Press, 2013.

INSTITUTO NACIONAL DE DERECHOS HUMANOS, Estudio de las condiciones carcelarias en Chile. Diagnóstico de cumplimiento de los estándares internacionales de derechos humanos, Santiago, 2013.

INSTITUTO NACIONAL DE DERECHOS HUMANOS, Estudio de las condiciones carcelarias en Chile. Informe 2014-2015. Seguimiento de recomendaciones y cumplimiento de estándares internacionales sobre derechos a la integridad personal, Santiago, 2017.

JAKOBS, Günther, La pena estatal: significado y finalidad, trad. y estudio preliminar de M. Cancio y B. Feijóo, Madrid: Thomson-Civitas, 2006.

JAKOBS, Günther, Sociedad, norma y persona en una teoría de un derecho penal funcional (traducción de M. Cancio Meliá y B. Feijóo Sánchez), Madrid: Civitas, 1996.

KANT, Immanuel, Metaphysische Anfangsgründe der Rechstlehre. Methaphysik der Sitten. Erster Teil, Hamburg: Felix Meiner Verlag, 1998.

KINDHAUSER, Urs, "La fidelidad al derecho como categoría de la culpabilidad" en: KINDHAUSER, Urs y MAÑALICH, Juan Pablo, Pena y culpabilidad en el estado democrático de derecho, Lima: Ara Editores, pp. 77-117, 2009.

KÜNSEMÜLLER, Carlos, "La judicialización de la ejecución penal", en Revista de Derecho, XVI, nº 1 (2005), pp. 113-123.

LABATUT, Gustavo, Derecho Penal. Parte General. Tomo I, $4^{\mathrm{a}}$ ed., Santiago: Ed. Jurídica de Chile, 1963.

LARRAURI, Elena y JACOBS, James, "Reinserción laboral y antecedentes penales", en Revista Electrónica de Ciencia Penal y Criminología № 13-09 (2011), en: http://criminet.ugr.es/recpc/13/recpc13-09.pdf

LASAGABASTER, Iñaki, Las relaciones de sujeción especial, Madrid: Civitas Ediciones, 1994.

LEÓN, Marco Antonio, Sistema carcelario en Chile. Visiones, realidades y proyectos (18121916), Santiago: Ediciones de la Dirección de Bibliotecas, Archivos y Museos, Centro de Investigaciones Barros Arana, 1996.

LÓPEZ BENÍTEZ, Mariano, Naturaleza y presupuestos constitucionales de las relaciones especiales de sujeción, Córdova: Civitas, 1994. 
HORVITZ, María Inés. "La insostenible situación de la ejecución de las penas privativas de libertad: ¿vigencia del Estado de derecho o estado de naturaleza?”.

LESCH, Heiko, La función de la pena, Trad. Sánchez-Vera, Javier, Madrid: Libros Dykinson, 1999.

MAÑALICH, Juan Pablo, "El derecho penitenciario entre la ciudadanía y los derechos humanos", en Derecho y Humanidades, $\mathrm{n}^{\circ} 18$ (2011), pp. 163-178.

MAÑALICH, Juan Pablo, "La pena como retribución”, en Estudios Públicos, nº 108 (2007), pp. 117-205.

MAÑALICH, Juan, "Pena y ciudadanía”, en Revista de Estudios de la Justicia $\mathrm{N}^{\circ} 6$ (2005), pp. 63-83.

MARSHALL, Pablo, "La persecución penal como exclusión política", en MUÑOZ, Fernando (ed.) Derecho, igualdad e inclusión, Santiago: LOM editores, 2013, pp. 69-91

MATHIESEN, Thomas, Prison on trial: a critical assessment, Londres: Sage, 1990.

MAYER, Otto, Das deutsche Verwaltungsrecht, 2 Aufl., Bd. I, 1896.

MERA, Jorge, "Adecuación del derecho penal chileno al derecho internacional de los derechos humanos", en MEDINA, Cecilia y MERA, Jorge (editores): Sistema Jurídico y Derechos Humanos. Cuadernos de Análisis Jurídico, Serie especial №6 (1996), pp. 343-476.

MIR PUIG, Santiago, "Recensión al libro Sociedad, norma y persona en una teoría de un derecho penal funcional", Revista de Derecho Penal y Criminología, $2^{\mathrm{a}}$ época, $\mathrm{N}^{\circ}$ 2 (1998), p.129.

MORALES, Ana María, WELSCH, Gherman y HURTADO, María Teresa, Estudio comparado sobre tribunales de ejecución de penas, Santiago: Fundación Paz Ciudadana, 2015.

MORALES, Ana María; MUÑOZ, Nicolás; WELSCH, Gherman y FABREGA, Jorge, La reincidencia en el sistema penitenciario chileno, Santiago: Fundación Paz Ciudadana y Universidad Adolfo Ibáñez, 2012.

MUÑOZ CONDE, Francisco, Introducción al Derecho Penal, Barcelona: Bosch, 1975.

NASH, Claudio, MILOS, Catalina, AGUILÓ, Pedro, Personas privadas de libertad y medidas disciplinarias en Chile: análisis y propuestas desde una perspectiva de derechos humanos, Santiago: INDH, Fac. Derecho U. de Chile, Unión Europea, 2013.

NOVOA, Eduardo, Curso de Derecho penal chileno. Parte General. Tomo II, $3^{\circ}$ ed. Ed. Jurídica de Chile, Santiago, 2005.

PALMER, Louis, The death penalty in the United States: a complete guide to federal and state laws, $2^{\text {nd }}$. Ed. Jefferson, North Carolina: Mc Farland \& Company, Inc. Publishers, 2014.

PEÑA, Ignacio, "Monitoreo telemático: análisis crítico desde la sociología del control y la economía del castigo", Revista de Estudios de la Justicia $\mathrm{N}^{\circ} 18$ (2013), pp. 161198.

PEÑARANDA, Enrique, "Sobre la influencia del funcionalismo y la teoría de los sistemas en las actuales concepciones de la pena y del concepto de delito", DOXA n ${ }^{\circ} 23$ (2000), pp. 289-321.

PIVEN, Frances y CLOWARD, Richard, Regulating the poor: the functions of public welfare, New York: Vintage, 1993.

POLITOFF, Sergio, MATUS, Jean-Pierre y RAMÍREZ, María Cecilia, Lecciones de Derecho Penal chileno, Parte General, Santiago: Ed. Jurídica de Chile, 2004. 
Polít. crim. Vol. 13, N²6 (Diciembre 2018) Art. 7, pp. 904-951.

[http://www.politicacriminal.cl/Vol_13/n_26/Vol13N26A7.pdf]

RIEGO, Cristian, "La crisis penitenciaria y el informe de la Cámara de Diputados", en BUSTOS, Juan et.al., Acerca de la cárcel, Cuadernos de Análisis Jurídico $\mathrm{N}^{\circ} 24$ (1993), Escuela de Derecho Universidad Diego Portales, pp. 65-87.

RIVACOBA, Manuel, Función y aplicación de la pena, Buenos Aires: Depalma, 1993.

RIVACOBA, Manuel, "Objeto, funciones y principios rectores del denominado derecho penitenciario", Revista de Derecho (CDE), año 1, nº 2, (2000) pp. 117-128.

RIVERA BEIRAS, Iñaki, La cuestión carcelaria. Historia, epistemología, derecho y política penitenciaria, Buenos Aires: Editores del Puerto, 2006.

ROXIN, Claus, Problemas Básicos del Derecho Penal, Traducción Luzón Peña, Diego, Madrid: Ed. Reus, 1976.

RUSCHE, Georg y KIRCHHEIMER, Otto, Pena y estructura social, Trad. García Méndez, Emilio, Bogotá: Temis, 1984.

SEPÚLVEDA, Eduardo, "El ordenamiento jurídico penitenciario chileno: sus reformas más urgentes”, en: HORVITZ, María Inés y STIPPEL, Jorg (coords.) Estado de derecho y reformas a la justicia, Santiago: U. Chile, Centro de Estudios de la Justicia, Heidelberg Center para América Latina, California Western School of Law, GTZ (Proyecto Reforma Judicial), 2005, pp. 121-140.

SILVA, Jesús María, "Del Derecho abstracto al Derecho "real", InDret N4 (2006), en: http://www.indret.com/pdf/377_es.pdf

SILVA, Jesús María, Aproximación al derecho penal contemporáneo, Barcelona: Bosch, 1992.

SPIEGEL, Ludwig, Derecho Administrativo, Barcelona-Buenos Aires: Editorial Labor, 1933.

STIPPEL, Jörg, Cárcel, derecho y política, Santiago: LOM Ediciones, 2013.

TAYLOR, Ian, WALTON, Paul y YOUNG, Jock, La nueva criminología. Contribución a una teoría social de la conducta desviada, Trad. Crosa, Adolfo, Buenos Aires: Amorrortu Editores, 1997.

TRAVIS, Jeremy; WESTERN, Bruce y REDBURN, Steve,cThe growth of incarceration in the United States: exploring causes and consequences, Committee on Causes and Consequences of High Rates of Incarceration; Committee of Law and Justice; Division of Behavioral and Social Services and Education, The National Academies Press (eds.), Washington D.C, 2014.

VALENZUELA, Jonatan, "Estado actual de la reforma al sistema penitenciario en Chile", Revista de Estudios de la Justicia $\mathrm{N}^{\circ} 6$ (2005), pp. 191-209.

WACQUANT, Loïc, Castigar a los pobres. El gobierno neoliberal de la inseguridad ciudadana, Barcelona: Gedisa, 2010.

WHITMAN, James, Harsch Justice. Criminal punishment and the widening divide between America and Europe, New York: Oxford University Press, 2003. 